\title{
FLOOD HAZARD ASSESSMENT FOR BRIDGE CROSSINGS OVER EPHEMERAL CHANNELS: A CASE STUDY OF THE MURCIA COAST (SE SPAIN)
}

\author{
C. CONESA-GARCÍA ${ }^{1 *}$, R. GARCÍA-LORENZO² \\ ${ }^{1}$ Department of Physical Geography, University of Murcia, \\ Campus de la Merced, 30001 Murcia, Spain. \\ ${ }^{2}$ Autonomous Community of Murcia Region, Environmental Integration and Information Service, \\ C/ Catedrático Eugenio Ubeda, s/n, 30008 Murcia, Spain.
}

\begin{abstract}
Bridges are usually built when traffic or the importance of the road network justifies the cost. Most road bridges are permanent structures and are vulnerable to extreme hydrologic events. Streams, particularly in semiarid regions, can significantly overflow their banks and may change course, defying the bridge's ability to perform its intended function. This article proposes a way of assessing flood hazards at bridge crossings over ephemeral streams. Two hazard indices associated with floodwaters at bridge crossings have been tested for ephemeral channels on the South-East coast of Spain: a Flood Hazard Index for bridge crossings $\left(F H I_{B C}\right)$, and a Geomorphological Hazard Index $\left(G H I_{B C}\right)$. $\mathrm{FHI}_{B C}$ is based on the exposure and effectiveness of drainage works for dealing with floods of different return period. The second index, $G H I_{B C}$, integrates parameters related to hydraulic resistance and potential bed erosion in large floods. Variables such as granular bed susceptibility to incision, critical velocity and transitory scouring have previously been estimated based on field data. The results show that $F_{B C}$ is an appropriate index for obtaining an overall evaluation of the flood hazard at this crossing type, while $G H I_{B C}$ provides useful information on the main hydromorphological factors which endanger the stability of the bridges over ephemeral streams. The joint implementation of both indices may also be an efficient tool for identifying high-risk crossings and improving the planning of future infrastructures over channels in the study area.
\end{abstract}

Evaluación del peligro de las aguas de avenida en cruces de puentes sobre ramblas: el caso de estudio de la costa murciana (SE de España)

RESUMEN. Los puentes se construyen normalmente cuando el tráfico o la importancia de la red de carreteras justifican su coste. La mayoría de los puentes de carreteras son estructuras permanentes, a menudo vulnerables ante sucesos hidrológicos extremos. Particularmente en medios semiáridos, las aguas de avenida pueden desbordar de forma significativa los márgenes del cauce y cambiar su curso, amenazando la capacidad de los puentes para realizar las funciones pre- 
vistas en su diseño. En este artículo se presenta una propuesta de evaluación del peligro de las avenidas en cruces de puentes sobre cauces efímeros. En concreto, se han ensayado dos índices de peligrosidad asociados a las aguas de avenida en cruces de puentes sobre ramblas de la franja costera de la Región de Murcia (SE de la Península Ibérica): Un Índice de Peligrosidad de Avenidas para cruces con puentes $\left(F H I_{B C}\right)$, y un Índice de Peligrosidad Geomorfológica $\left(G H I_{B C}\right)$ para el mismo tipo de cruces. $\mathrm{FHI}_{B C}$ se basa en el grado de exposición y efectividad de las obras de drenaje ante inundaciones con diferentes tiempos de retorno. El segundo índice, $G_{H C}$, integra parámetros relativos a la resistencia hidráulica del lecho fluvial y a su erosión potencial ante grandes avenidas. Variables como la susceptibilidad granular a la incisión del lecho, la velocidad crítica y la erosión transitoria han sido estimadas previamente a partir de datos de campo. Los resultados muestran que $F_{B C}$ proporciona un buen indicador para obtener una evaluación global de la peligrosidad de las avenidas en este tipo de cruces, mientras que $G_{B C}$ aporta una información útil sobre los factores hidromorfológicos que ponen en peligro la estabilidad de los puentes en cauces efímeros (ramblas y ríos-rambla). La aplicación conjunta de ambos índices puede ser además un instrumento eficiente para la identificación de cruces de alto riesgo y para la mejora de ciertas infraestructuras potencialmente críticas.

Key words: floods, bridge crossings, ephemeral channels, hazard index, South East Spain.

Palabras clave: avenidas, cruces con puentes, cauces efímeros, índice de peligrosidad, Sureste de España.

Received 30 October 2013

Accepted 26 January 1014

*Corresponding author: Department of Physical Geography, University of Murcia, Campus de la Merced, 30001 Murcia, Spain. E-mail: cconesa@um.es

\section{Introduction}

The bridge is widely accepted as the best option for crossings with a high volume of traffic, large and variable water volume, high debris-potential, a sensitive channel bottom and banks, and a large elevation difference between the channel and road grade (US Department of Transportation, 2009). There is a wide range of technical literature about the hydraulic design and behaviour of the bridges (Woo, 1988; Kranc et al., 1997). In Europe physical hydraulic modelling, often in conjunction with numerical computer modelling, is used as an integral part of the hydraulic design process for bridge foundations and countermeasures (TRB, 1999). It is also common for road guides to include instructions and rules on the design and maintenance of drainage systems (NRB, 1977; NCHRP, 1979; AASHTO, 1999, 2003a, 2003b, 2004). In Spain Road Guideline 5.1-IC on Drainage (MOPU, 1965) and Road Guideline 5.2-IC on Surface Drainage (MOPU, 1990) are usually applied. Other factors have an influence on the design of these 
transversal drainage works apart from hydraulic conditions: road characteristics, channel morphology, assessment of the damage caused by flow concentration and other economic considerations relating to the cost of building and maintaining the road (Jaén Diego and Romana García, 2004; Pedernal Álvarez and Barahona Fernández, 2004). Evaluating both scour at bridges and stream instability has been an important aim in engineering in recent decades (Brice, 1984; Lagasse et al., 2001b; Richardson and Davis, 2001; U.S. Department of Transportation, 2001, 2009; Deng and Cai, 2010). A risk-based analysis is also usually applied in order to develop plans of action for multiple bridges with scour critical ratings (Lounis, 2004) and to obtain optimization models for bridge maintenance planning (Yang and Hsu, 2010). For many urban areas, stream-bank erosion is analyzed as an ongoing threat to roads, bridges and other drainage structures (Konrad and Booth, 2002). Nevertheless, few studies of bridge crossing effects and stream channel adjustments following urbanization have been undertaken in dryland environments (Chin and Gregory, 2001).

This study presents a proposal for calculating flood hazard indices for bridges crossing ephemeral channels using hydrological, hydraulic and morphological criteria and exposure factors. This proposal has been tested on the southern coast of Murcia (Spain), where there is a dense network of roads affected by torrential ephemeral streams (locally known as "ramblas"). Real situations observed in situ, meteorological and hydrological data and Drainage Work Project Reports of the Segura River Basin Authority and the Road and Highway Maintenance Department from the Murcia Regional Government have been used to prove the effectiveness of bridge crossings. An increasing development of road infrastructures in the Region of Murcia is not always accompanied by a proper drainage work design in accordance with fluvial dynamics. Bridges are often the preferred option for road crossings over the main ephemeral streams in this area. However, the poor location of footings, foundations, or abutments can cause channel scour and contribute to debris blockage. In the coastal area of Murcia there are different examples of dangerous bridge crossings in which the drainage system has insufficient hydraulic capacity or is highly exposed to negative geomorphological impacts during floods. Under high water levels and flood stages, critical thresholds in bed and channel bank stability are frequently exceeded. Bridge pier scouring processes in fine-bed alluvial channels and deep rills on embankments and slopes constitute a serious danger to the stability of the affected road-section and to the drainage structure itself in such cases.

The lack of maintenance can cause the collapse of a bridge (Sobanjo et al., 2010). In addition to inappropriate channel maintenance, uncontrolled debris and rubble spillages into ramblas increase obstacles and feed the bedload in periods of flash-floods. This directly leads to the blockage of the drainage structure and an increase in the flow height, which finally exceeds the road level and floods it. The low hydraulic effectiveness of some bridges set up in the area of the ramblas turns most of these factors into warning signs during floods. Evidence for this is provided by the hazard indices obtained at rambla crossings, including those related to the geomorphological impact on channels in flood events. In such cases, accelerated erosion brought about by the failure of channel crossing structures is usually due to the poor location of the crossing and an inadequate design for 
handling peak flow and debris. In the present study the $\mathrm{FHI}_{\mathrm{BC}}$ and $\mathrm{GHI}_{\mathrm{BC}}$ indices have been used. These were proposed by Conesa García and García Lorenzo (2011) for evaluating flood hazards at bridge crossings over dry channels. They have been applied to the southern coast of Murcia in an attempt to define the hazard level of each crossing and to identify the most dangerous points in this area. A complementary objective of this study is to implicitly find out the relative weighting of the different factors affecting the design of both indices. The ultimate aim is to provide a useful instrument for government administrations and institutions involved in flood hazard management plans. The results could help in making decisions about territorial planning, particularly in those areas where torrential rains and the unpredictability of floodwaters pose constant threats, owing to the frantic pace of human occupation that has taken place in recent times.

\section{Study area}

The bridge crossings under study are located in different ephemeral streams flowing directly into the Mediterranean Sea on the Murcia coast (South East Spain). Their catchments cover almost $200 \mathrm{~km}$ of coastline, between the areas of Águilas and La Unión, located in the southeastern sector of the Betica coastal zone. In this area, the coastal mountain range consists of a large string of steep reliefs that is generally near the coastline. The current coastal depressions are spread out over a few miles at the foot of this range. The mountainous strip is characterized by the presence of metamorphic, limestone, and dolomite materials from the Precambrian to the Triassic period, whereas the coastal depressions have been developed on Neogene-Quaternary-filled sediments.

The surface runoff is organized into independent drainage networks, with a direct outflow into the sea, a predominantly dendritic structure, steep slopes, and a torrential

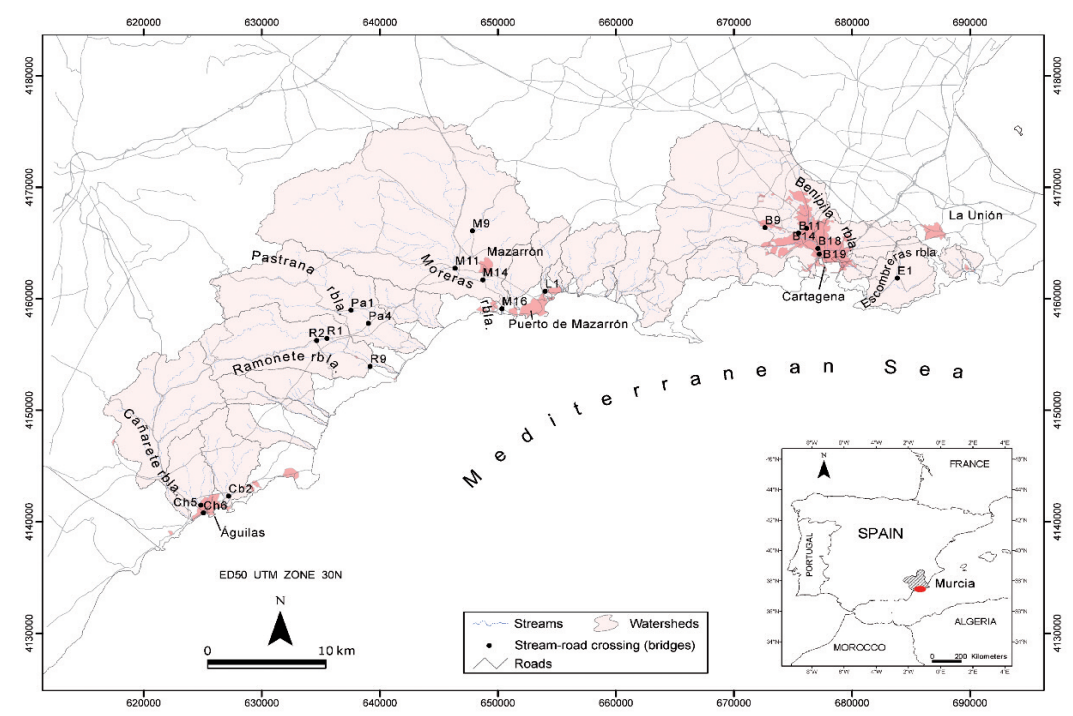

Figure 1. Study area and location of road-crossing bridges over ephemeral channels in the Murcia region, Spain. 
hydrological regime (Conesa-García, 2005). These networks belong to 52 basins with sizes ranging between 0.51 and $246.5 \mathrm{~km}^{2}$ (Fig. 1). Almost half of them are very small, less than $10 \mathrm{~km}^{2}$, and can be completely covered by the rain in just one storm event (Alonso-Sarría et al., 2002). Another 11 basins also have small areas, of less than $30 \mathrm{~km}^{2}$, which can be completely affected by mesoscale precipitation. Only five basins are larger than $70 \mathrm{~km}^{2}$, drained by the Benipila, Cañarete, Moreras, Pastrana, and Ramonete ephemeral channels. For this study, 19 road-crossing bridges on ephemeral streams have been selected from these large basins and also from some of the smaller ones (Escombreras, Culebras and Lorentes basins), which are at a high risk from flash floods (Table 1).

Table 1. Location of road-stream crossings (bridges) in the studied ephemeral channels.

\begin{tabular}{|c|c|c|c|c|c|}
\hline $\mathbf{R S C}^{\mathrm{a}}$ & $\begin{array}{l}\text { Ephemeral } \\
\text { channel }\end{array}$ & Basin & $\mathbf{X}$ & $\mathbf{Y}$ & $\begin{array}{c}\text { Crossing } \\
\text { description }\end{array}$ \\
\hline B9 & Ladrillar & Benipila & 672641 & 4166370 & E-20 and Benipila Rambla \\
\hline B11 & Benipila & Benipila & 675487 & 4165879 & AP-7 and Benipila Rambla \\
\hline B14 & Los Dolores & Benipila & 676173 & 4166296 & $\begin{array}{l}\text { Road to Nueva Cartagena and } \\
\text { Dolores Rambla }\end{array}$ \\
\hline $\mathrm{B} 18$ & Benipila & Benipila & 677126 & 4164504 & $\begin{array}{l}\text { Road to Conciliación (Cartagena) } \\
\text { and Benipila Rambla }\end{array}$ \\
\hline B19 & Benipila & Benipila & 677231 & 4164003 & $\begin{array}{l}\text { Road to Concepción (Cartagena) } \\
\text { and Benipila Rambla }\end{array}$ \\
\hline E1 & Escombreras & Escombreras & 683851 & 4161838 & MU-320 and Escombreras Rambla \\
\hline L1 & Los Lorentes & Los Lorentes & 654015 & 4160671 & N-332-1 and Lorentes Rambla \\
\hline M9 & Las Yeseras & Las Moreras & 647847 & 4166082 & MU-603 and Yeseras Rambla \\
\hline M11 & Las Moreras & Las Moreras & 646389 & 4162733 & D-4 and Moreras Rambla \\
\hline M14 & Las Moreras & Las Moreras & 646662 & 4162273 & N-332-1 and Moreras Rambla \\
\hline M16 & Las Moreras & Las Moreras & 650024 & 4161934 & D-6 and Moreras Rambla \\
\hline $\mathrm{Pa} 1$ & Pastrana & Pastrana & 637562 & 4158964 & D-5 and Pastrana Rambla \\
\hline $\mathrm{Pa} 4$ & Pastrana & Pastrana & 639018 & 4157925 & $\begin{array}{l}\text { Local road close to N-332-2 and } \\
\text { Pastrana Rambla }\end{array}$ \\
\hline R1 & Río Amir & Ramonete & 635516 & 4156444 & N-332-2 and Amir Rambla \\
\hline $\mathrm{R} 2$ & Los Miñarros & Ramonete & 634647 & 4156253 & D-20 and Miñarros Rambla \\
\hline R9 & Las Planas & Ramonete & 639172 & 4153929 & $\begin{array}{l}\text { D-21 and a tributary gully of } \\
\text { Ramonete Rambla }\end{array}$ \\
\hline $\mathrm{Cb} 2$ & Culebras & Culebras & 627187 & 4142300 & D-14 and Culebras Rambla \\
\hline Ch5 & Charco & Charco & 624850 & 4141490 & Lorca road and Charco Rambla \\
\hline Ch6 & Charco & Charco & 625058 & 4140789 & $\begin{array}{l}\text { Urban road in Águilas and Charco } \\
\text { Rambla }\end{array}$ \\
\hline
\end{tabular}

${ }^{a}$ Road Stream Crossing. ${ }^{\mathrm{b}}$ Road and rambla names. 


\section{Methodology}

Two flood hazard indices for bridge crossings were proposed: a Flood Hazard Index for bridge crossings $\left(\mathrm{FHI}_{\mathrm{BC}}\right)$, and a Geomorphological Hazard Index $\left(\mathrm{GHI}_{\mathrm{BC}}\right)$. $\mathrm{FHI}_{\mathrm{BC}}$ combined an exposure factor with an inefficiency index of drainage works for different return periods. To obtain hydrological and hydraulic data, HEC GeoRAS was used in a GIS environment (Fig. 2). In particular, its 4.0 version provided details about stable and unstable flow, sub-critical and supercritical flows, and calculations of mixed regimen profiles, already tested on ephemeral drainage networks (García Lorenzo and Conesa García, 2011). The flow profiles were obtained using the standard procedure: the transmission of flooding was processed increasingly for each coordinate and roughness change. The software included applications for hydraulics in bridges, the analysis of confluences and drainage networks, and the interpolation of channel cross-sections.

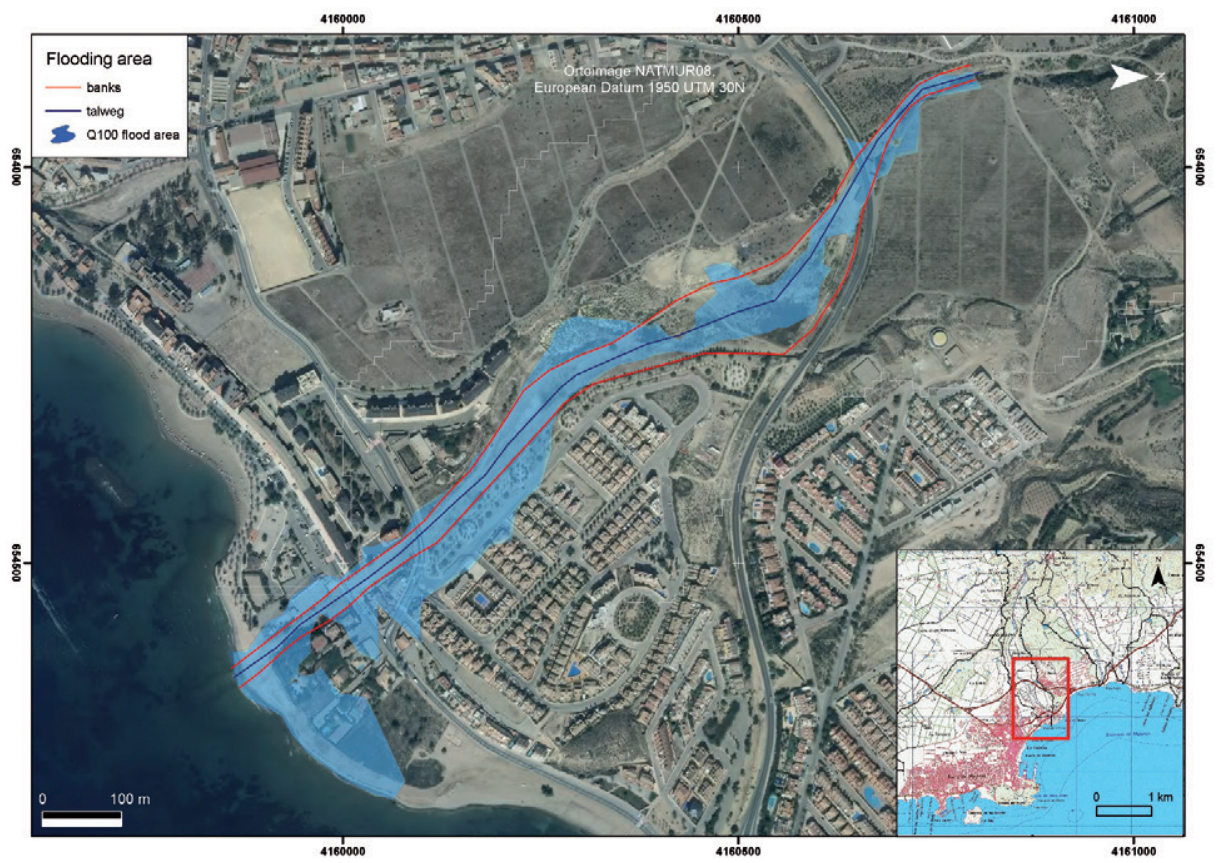

Figure 2. Flooding area obtained using HEC-GeoRAS for a 100-year flood in the Lorentes Rambla.

Different geomorphological hazard parameters were also used as significant variables affecting the stability of the structure, especially those relating to bed scour processes such as critical flow velocity ( $\mathrm{Vcr}^{*}$ ) and general transitory scouring (GTS), both reached during the peak flow. Variations in bed elevation during flow events or after bank hardening can result in the undermining of bank protection works including longitudinal structures. Methods for estimating maximum scour in order to design stable bank protection are described in HDS 6 (Richardson et al., 2001), HEC-18 
(Richardson and Davis, 2001) and HEC-20 (Lagasse et al., 2001a). During a flood, scour is often not visible, and during the falling stage of a flood, scour holes are generally filled in. Visual monitoring during a flood and inspection after a flood cannot fully determine that a bridge is safe (Lagasse et al., 1998). Empirical methods, based on this critical velocity (Shields, 1936; Lischtvan and Lebediev, 1959; Neill, 1968), are usually applied in ephemeral channels to estimate the critical mean flow velocity and the transitory scouring ratios during flood events (Martín Vide et al., 1993). This is the case in the present paper, where Neill's method has been used to evaluate the general transitory erosion upstream from bridges.

\subsection{Flood Hazard Index for bridge crossings $\left(F H I_{B C}\right)$ in ephemeral channels}

As a first approximation, a specific flood hazard index of the road was adopted, based purely on the combination of three data layers: i) coverage of the road network with types of road specifications; ii) vector data of stream reaches with a flood hazard or potential overflow; and iii) vector data of stretches with a different road category and daily traffic intensity (DTI).

The vector data on the demarcation of basins were used to intersect road coverage. By overlaying both coverages, other field data containing a code for each rambla basin were added to the road network. Then, each road stretch was defined depending on category. A third phase involved reclassifying all the roads in terms of the hazard type and level. The vector data about floods in lowlands and potential overflowing in the middle and higher reaches of ramblas and gullies were superimposed onto the road network coverage in each basin, producing a hazard map which included road stretches with overflow and flooding hazards. From such data, stream crossings (RSC) on road networks representing overflow hazards were located. Finally, Bridge crossings, which are suspected of being affected by flood events, were identified and classified.

The exposure levels were established in accordance with two criteria: type of road and daily traffic intensity. To classify roads an updated inventory produced by the General Directorate for Roads, in the Autonomous Community of the Murcia Region, was used. The traffic intensity data came from Average Daily Traffic (ADT) and Average Daily Heavy Traffic (ADHT) counts provided in 2007 by the same Directorate General (Conesa García and García Lorenzo, 2011). In the weighting of road category more weight was given to major roads. The average value was 6 for highways, 5 for national roads, 4 for major regional roads, 3 for minor regional roads, 2 for secondary local highways (tertiary regional roads) and 1 for the local roads, tracks and cross-streets. Regarding the weighting of daily traffic intensity, the following categories were established: 1 for ADT of less than 250 vehicles per day; 2 for $250<$ ADT $<1000$; 3 for $1000<$ ADT $<2500$; 4 for $2500<$ ADT $<5000$; 5 for $5000<$ ADT $<7500$; and 6 for ADT higher than 7500 vehicles per day.

$$
I_{E X P}=\left[\left(\frac{A D T+A D H T}{2}\right)+C_{R}\right] \frac{1}{12}
$$


where $\mathrm{I}_{\mathrm{EXP}}$ is the exposure index, ADT the average daily traffic (weighted values), ADHT the average daily heavy traffic (weighted values), and $C_{R}$ the road category (weighted values). The value of 12 is a constant value for defining the variation range of the coefficient between 0 and 1 .

Finally, the Flood Hazard Index for bridge crossings $\left(\mathrm{FHI}_{\mathrm{BC}}\right)$ is calculated, considered as the product of the Exposure Index $\left(\mathrm{I}_{\mathrm{EXP}}\right)$ and the Inefficiency Index $\left(\mathrm{INEF}_{\mathrm{B}}{ }^{*}\right)$ for drainage works (Conesa García and García Lorenzo, 2011).

$$
\begin{gathered}
F H I_{B C}=\left[\left(I_{E X P}\right) \cdot \mathbf{2}\right] \cdot I N E F_{B}^{*} \\
I N E F_{B}=\frac{1}{A E F_{B}} \\
I N E F_{B}^{*}=I N E F_{B}^{\frac{1}{I N E F_{B}}} \\
A E F_{B}=\frac{\left[\left(\frac{M Q_{S}}{Q_{100}}\right) \cdot \mathbf{0 . 1}+\left(\frac{M Q_{S}}{Q_{200}}\right) \cdot 0.05+\left(\frac{M Q_{S}}{Q_{500}}\right) \cdot 0.02\right]}{0.17}
\end{gathered}
$$

where $\mathrm{INEF}_{\mathrm{B}}$ is the Inefficiency Index, $\mathrm{INEF}_{\mathrm{B}}{ }^{*}$ is the Inefficiency Index adjusted for a weighting factor with a potential function, $\mathrm{AEF}_{\mathrm{B}}$ refers to the average degree of hydraulic efficiency, $\mathrm{MQ}_{\mathrm{S}}$ is the maximum discharge which a bridge span allows to pass, $\mathrm{Qx}$ is the expected peak discharge corresponding to a return period of $\mathrm{x}$ years at each bridge crossing (García Lorenzo and Conesa García, 2011). The value 0.17 is the sum of the annual exceedance probabilities equivalent to 100, 200 and 500-year floods. According to this formula, a road-rambla crossing equipped with a bridge or pontoon is considered to be hazardous when $\mathrm{FHI}_{\mathrm{BC}} \geq 0.75$, and can become high hazard when $\mathrm{FHI}_{\mathrm{BC}} \geq 1$ (Table 2).

Table 2. Categories and ranges of values for $A E F_{B}, I N E F_{B}, I E X P$ and $F H I_{B C}$ indexes estimated for bridge crossings.

\begin{tabular}{|c|c|c|c|c|c|}
\hline Category & $\mathbf{A E F}_{\mathbf{B}}$ & $\mathbf{I N E F}_{\mathbf{B}}$ & Category & $\mathbf{I}_{\mathbf{E X P}}$ & $\mathbf{F H I}_{\mathbf{B C}}$ \\
\hline Very low & $<0.5$ & $<0.5$ & Low & $\leq 0.33$ & $<0.75$ \\
\hline Low & $0.5-1.0$ & $0.5-1.0$ & Moderate & $0.33-0.5$ & $0.75-1.0$ \\
\hline High & $1.0-1.5$ & $1.0-1.5$ & High & $0.5-0.67$ & $1.0-2.0$ \\
\hline Very high & $>1.5$ & $>1.5$ & Very high & $\geq 0.67$ & $>2.0$ \\
\hline
\end{tabular}

$\mathrm{AEF}_{\mathrm{B}}=$ average degree of hydraulic efficiency; $\mathrm{INEF}_{\mathrm{B}}=$ hydraulic inefficiency Index; $\mathrm{I}_{\mathrm{EXP}}=$ exposure index; $\mathrm{FHI}_{\mathrm{BC}}=$ Flood Hazard Index for bridge crossings. 


\subsection{Geomorphological Hazard Index $\left(G H I_{B C}\right)$ for ephemeral channels}

The $\mathrm{GHI}_{\mathrm{BC}}$ Index proposed here for these types of crossings is based on the consideration of parameters relating to hydraulic resistance in granular beds and potential channel scouring during floods. Indeed, most of the stability problems in bridges crossing these ephemeral channels are due to high streambed erosion rates produced during flash flood events. Live-bed scour occurs where there is transport of bed material from the upstream reach onto the crossing. This process can modify the channel cross-sections close to bridges leading to a narrower channel and locally affecting piers, abutments and other structural elements. As scour develops, shear stress in the contracted section decreases as a result of a larger flow area and decreasing average velocity. For live-bed scour, maximum scour occurs when the shear stress reduces to the point that sediment transported in equals the bed sediment transported out and the conditions for sediment continuity are in balance. Under such conditions, the estimate of $\mathrm{GHI}_{\mathrm{BC}}$ in the reach immediately upstream of the crossing provides an adequate hazard index associated with potential bed scour. This index includes specific variables such as threshold velocity for initial particle motion (critical velocity), bed stability (degree of surface bed armouring) and general transitory scour (GTS) (Conesa-García and García-Lorenzo, 2009).

$$
\begin{gathered}
G H I_{B C}=\frac{\left[G S I+\left(V_{c}^{*} \cdot G T S^{*}\right)\right]}{2} \\
G S I=1-\left[\left(A r \cdot D_{84}\right) \cdot 5\right] \\
V_{c}^{*}=\frac{\left[\left(V_{c 100}\right) \cdot 0.1+\left(V_{c 200}\right) \cdot 0.05+\left(V_{c 500}\right) \cdot 0.02\right]}{0.17} \\
G T S^{*}=\frac{\left[\left(G T S_{100}\right) \cdot 0.1+\left(G T S_{200}\right) \cdot 0.05+\left(G T S_{500}\right) \cdot 0.02\right]}{0.17}
\end{gathered}
$$

where GSI is the granular bed susceptibility to incision, which can vary from 0 to 1 (Table 3). Ar is the bed armouring rate measured as the ratio of surface to subsurface bed material grain size; The particle size corresponding to the $84^{\text {th }}$ percentile of the total sample weight $\left(D_{84}\right)$ was used as the characteristic grain size for calculating Ar. $V_{c}$ is the critical velocity obtained using the Neill's method for calculating transitory scour rates (GTS) (Neill, 1968). $\mathrm{V}_{\mathrm{c}}^{*}$ and GTS* are the weighted averages of both variables calculated according to the occurrence probability of GTS rates attributable to 100, 200 and 500-year floods (Equations 3c and 3d). Both variables, critical velocity and general transitory scouring, affect the stability of pier footings and bridge foundations in general, and can be appropriate indicators for assessing geomorphological hazards in these crossings. 
Table 3. Categories and ranges of values for $\mathrm{GHI}_{B C}$ and associated parameters.

\begin{tabular}{|c|c|c|c|c|c|}
\hline Category & GTS & GTS* & $\mathbf{V}_{\mathbf{c}}{ }^{*} \cdot \mathbf{G T S} *$ & GSI & GHI $_{\mathbf{B C}}$ \\
\hline Low & $<0.3$ & $<0.25$ & $<0.5$ & $<0.25$ & $<0.25$ \\
\hline Moderate & $0.3-0.6$ & $0.25-0.5$ & $0.5-1.0$ & $0.25-0.50$ & $0.25-0.75$ \\
\hline High & $0.6-1.2$ & $0.50-1.0$ & $1.0-1.5$ & $0.50-0.75$ & $0.75-1.25$ \\
\hline Very high & $>1.2$ & $>1.0$ & $>1.5$ & $>0.75$ & $>1.25$ \\
\hline
\end{tabular}

GTS $=$ transitory scour rate; $\mathrm{V}_{\mathrm{c}}{ }^{*}$ and GTS* $=$ weighted averages of $\mathrm{V}_{\mathrm{c}}$ (critical velocity) and GTS calculated according to the occurrence probability of 100, 200 and 500-year floods; GSI = granular bed susceptibility to incision; $\mathrm{GHI}_{\mathrm{BC}}=$ Geomorphological Hazard Index. From Conesa García and García Lorenzo (2011).

Apparently transitory scouring is caused by an increase in shear stress on the bed, connected to a rise in water level (Martín Vide, 1997), but this is not a satisfactory explanation if there is no imbalance between the transport capacity $\left[\mathrm{q}_{\mathrm{s}} \leftrightarrow\left(\tau_{0}-\tau_{\mathrm{c}}\right)\right]$ and the sediment carried down from upstream. Meanwhile, Hjulstrom and his successors (Hjulstrom, 1935; Lischtvan and Lebediev, 1959; Neill, 1968; Levi, 1981; Maizels, 1983; Van Rijn, 1984; Maza and García Flores, 1997) have determined a minimum velocity of erosion and sedimentation for each particle size at a given depth.

\section{Flood hazard assessment for bridge crossings over ephemeral channels (ramblas)}

\subsection{Degree of Exposure, efficiency of drainage works and flood hazard index}

Tables 4 and 5 show the parameters used to calculate the hydraulic capacity and efficiency of bridges and pontoons in comparison with the flow estimated for different return periods. In addition, overflow discharges, and the exposure and flood hazard indices were obtained for those points. The type of road and the average daily intensities (including heavy vehicles) for each road-rambla crossing are also indicated. By comparing the average levels of overflow and bridge drainage in the analyzed crossing sections (RSC), it can be seen that in most cases $(63 \%)$ the height of the bridge span is above the overflowing level. This partly ensures the efficiency of their drainage devices, no matter what is the magnitude of the flood. In the $37 \%$ remaining cases, the height of the main span is under the top of the banks and the nearby channel retaining walls. In these cases, its hydraulic efficiency becomes dependent on the frequency and magnitude of flood discharges.

By comparing the maximum flow drained by bridges and pontoons with flood discharges estimated for different return periods, it can be seen that nearly all the spans of bridges drain peak discharges with return periods of less than 100 years.

Only three structures, in crossings R9, B14 and E1, are unable to evacuate the water of 100-year floods. R9 is the D-21 road crossing the Planas Gully (a tributary of the Ramonete Rambla). At point B14, a regional road crosses the canal link between 
the Dolores Rambla and the Benipila Rambla in the west sector of Cartagena (Fig. 3). In both cases, the drainage structures are pontoons with one or several boxes made of reinforced concrete.

Point E1 corresponds to the MU-320 road crossing the Escombreras Rambla over a little bridge with the structure of formwork in bad conditions (Fig. 3). The drainage is carried out through three arches with a height of 1.5 metres and a width of $9 \mathrm{~m}$ which together give a maximum combined capacity of $71 \mathrm{~m}^{3} \mathrm{~s}^{-1}$ (Table 4).
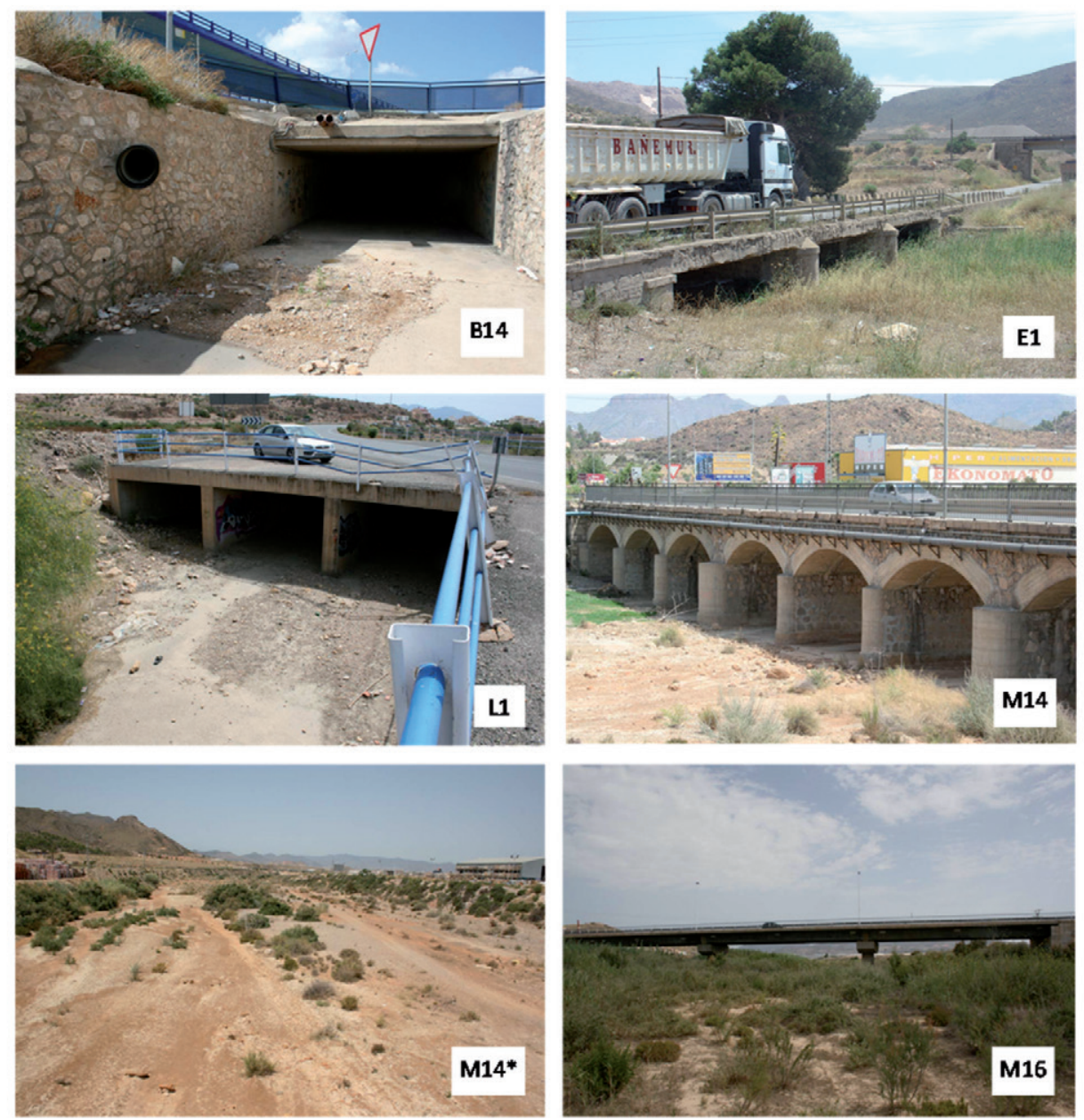

Figure 3. Pontoon in point B14: road crossing the connecting channel between the Dolores

Rambla and the Benipila Rambla. Point E1: the Escombreras Rambla intersecting with Mu-320 (local tertiary road). Point L1: crossing of N-332-1 road over the Lorentes Rambla saved by pontoons. Point M14: road N-332-1 over the Moreras Rambla next to Mazarrón (lower reach). Point M14*: sandy loam bed upstream from the M14 bridge over the Moreras Rambla. Point M16: the intersection of the Moreras Rambla with D-6 (local tertiary road) which links Mazarrón Port with Bolnuevo (Águilas). 
Table 4. Drainage capacity in bridges and pontoons compared with the discharges estimated for different return periods and flooding levels.

\begin{tabular}{|c|c|c|c|c|c|c|c|c|c|c|}
\hline RSC & $Q_{100}$ & $\mathbf{Q}_{200}$ & $Q_{500}$ & $\begin{array}{l}H_{o v} \\
(\mathbf{m})\end{array}$ & $\underset{\left(\mathbf{m}^{3} \mathbf{s}^{-1}\right)}{\mathbf{Q}}$ & $\begin{array}{l}\mathbf{H}_{\text {sp }} \\
(\mathrm{m})\end{array}$ & $\begin{array}{c}\text { SCSA } \\
\left(\mathbf{m}^{2}\right)\end{array}$ & $\begin{array}{c}\text { MQs } \\
\left(\mathbf{m}^{3} \mathbf{s}^{-1}\right)\end{array}$ & $\begin{array}{c}\text { MQs } \\
\left(\mathbf{m}^{3} \mathbf{s}^{-1}\right) \\
\mathbf{n}+\mathbf{0 . 0 1}\end{array}$ & $\begin{array}{c}\text { MQs } \\
\left(\mathrm{m}^{3} \mathbf{s}^{-1}\right) \\
\mathrm{n}+\mathbf{0 . 0 2}\end{array}$ \\
\hline B9 & 93.9 & 126.2 & 176.4 & 3.5 & 417.8 & 2.6 & 62 & 151.8 & 135 & 117 \\
\hline B11 & 231.4 & 312.8 & 439.5 & 2.2 & 206.9 & 3.0 & 174 & 278.4 & 252 & 224 \\
\hline B14 & 152.3 & 222.2 & 296.7 & -- & -- & 2.6 & 17 & 54.4 & 45 & 39 \\
\hline B18 & 572.1 & 740.4 & 997.4 & 5.7 & 955.0 & 5.7 & 160 & 1072.0 & 927 & 820 \\
\hline B19 & 572.1 & 740.4 & 997.4 & 5.5 & 1125.0 & 5.0 & 175 & 960.0 & 847 & 736 \\
\hline E1 & 92.3 & 113.0 & 143.3 & 2.0 & 122.0 & 1.4 & 27 & 71.0 & 59 & 52 \\
\hline L1 & 107.0 & 131.7 & 165.9 & 4.0 & 201.0 & 2.6 & 60 & 170.0 & 148 & 130 \\
\hline M9 & 129.0 & 152.0 & 183.0 & 1.5 & 257.0 & 1.9 & 58 & 213.0 & 194 & 171 \\
\hline M11 & 422.0 & 533.9 & 695.4 & 2.1 & 785.0 & 7.3 & 280 & 812.0 & 724 & 646 \\
\hline M14 & 468.8 & 593.6 & 774.1 & 3.9 & 1200.0 & 5.3 & 285 & 830.0 & 743 & 656 \\
\hline M16 & 515.5 & 651.2 & 847.2 & 3.5 & 950.0 & 5.4 & 520 & 1080.0 & 959 & 868 \\
\hline $\mathrm{Pa} 1$ & 272.7 & 342.4 & 444.3 & 1.2 & 250.0 & 3.2 & 130 & 845.0 & 765 & 678 \\
\hline $\mathrm{Pa} 4$ & 355.2 & 451.9 & 593.5 & 2.4 & 440.0 & 3.2 & 146 & 630.0 & 567 & 518 \\
\hline $\mathrm{R} 1$ & 136.8 & 179.1 & 242.4 & 1.3 & 149.5 & 6.0 & 230 & 1124.0 & 1030 & 909 \\
\hline R2 & 148.5 & 193.1 & 260.2 & 4.0 & 880.0 & 3.1 & 40 & 172.0 & 154 & 137 \\
\hline R9 & 42.8 & 54.4 & 71.4 & 4.2 & 335.0 & 3.3 & 10 & 40.6 & 34 & 29 \\
\hline $\mathrm{Cb} 2$ & 103.6 & 154.9 & 160.5 & 1.7 & 103.6 & 2.6 & 32 & 160.5 & 141 & 128 \\
\hline Ch5 & 89.7 & 124.1 & 180 & 1.5 & 155.0 & 2.2 & 80 & 235.0 & 205 & 187 \\
\hline Ch6 & 89.7 & 124.1 & 180 & 1.6 & 314.0 & 1.7 & 90 & 330.0 & 298 & 268 \\
\hline
\end{tabular}

RSC = road-stream crossing; $\mathrm{H}_{\mathrm{ov}}=$ overflow level; $\mathrm{Q}_{\mathrm{ov}}=$ overflow discharge; $\mathrm{H}_{\mathrm{sp}}=$ average span height; SCSA $=$ span cross-sectional area $\left(\mathrm{m}^{2}\right)$.

Table 5 shows the values of variables used to estimate the exposure road index $\left(\mathrm{I}_{\mathrm{EXP}}\right)$ and the efficiency average degree for bridge and pontoon drainage $\left(\mathrm{AEF}_{\mathrm{B}}\right)$, as well as the difference between the height to top of arch $\left(\mathrm{H}_{\mathrm{sp}}\right)$ and the average overflow level $\left(\mathrm{H}_{\mathrm{ov}}\right)$ upstream from the bridge. When $\mathrm{H}_{\mathrm{sp}} / \mathrm{H}_{\mathrm{ov}}$ takes a negative value and the discharge capacity of the arch spans is not sufficient to drain a 500-year peak flow its efficiency is put into question, although the hazard index is no greater than the value 1 .

According to the proposed methodology, with the exception of $\mathrm{Pa} 1$ and $\mathrm{Pa} 4$, the rest of the road-rambla crossings $(90 \%)$ showed a high or very high degree of exposure. More than $37 \%$ of bridge crossings had an average traffic intensity rated up to 7500 vehicles per day, $17.7 \%$ recorded an ADT from 5000 to 7500 vehicles per day and $26.3 \%$ between 2500 and 5000 vehicles per day. In relation to Average Daily Heavy Traffic, more than $47 \%$ of the crossings reached an ADHT from 400 to 1600 vehicles per day. Regarding road categories, 58\% are first-class roads (highways, 
national roads, major regional roads). The highest levels of exposure were produced in crossings of these roads over some of the main ramblas on coastal areas (Charco, Ramonete, Moreras, Lorentes and Benipila ramblas). In the Ramonete Rambla the most exposed are the crossings of the road N-332-2 along its middle reach (e.g. R1), which despite running through unpopulated areas, may endanger a high traffic volume over the summer months (Table 5). The crossings of the Moreras Rambla M9, M11 and M14 are in the neighbourhood of Mazarrón, and crossing L1 of the N-332-1 road with the Lorentes Rambla is located in the north-east entrance of Mazarrón Port. Finally, the crossings of The Charco Rambla Ch5 and Ch6, and Benipila Rambla B11, B14, B18 and B19, located in the lower reaches of both ramblas, have a high exposure in the urban centres of Águilas and Cartagena respectively. Traffic, road infrastructures and populations close to these critical points are directly exposed during large floods.

Table 5. Variables used for estimating exposure index of roads $\left(I_{E X P}\right)$ and the average efficiency for drainage of bridges and pontoons $\left(A E F_{B}\right)$.

*Inadequate drainage capacity for return periods longer than 500 years.

\begin{tabular}{|c|c|c|c|c|c|c|c|c|c|c|c|c|}
\hline RSC & ADT & ADHT & $\mathrm{C}_{\mathrm{R}}$ & $\mathbf{I}_{\mathbf{E X P}}$ & $\underset{\left(\mathbf{m}^{3} \mathbf{s}^{-1}\right)}{\mathrm{MQ}_{\mathrm{S}}}$ & \begin{tabular}{|c|}
$\mathbf{M Q}_{\mathrm{S}}$ \\
/ Q100
\end{tabular} & \begin{tabular}{|c|}
$\mathbf{M Q}_{\mathrm{S}}$ \\
/ Q200
\end{tabular} & $\begin{array}{c}\mathbf{M Q}_{\mathrm{S}} \\
\text { / Q500 }\end{array}$ & $\mathbf{A E F}_{\mathbf{B}}$ & $\underset{\mathrm{sp}}{\mathbf{H}_{\mathrm{m}}-\mathbf{H}_{\mathrm{ov}}}$ & $\begin{array}{l}\text { Suitable } \\
\text { capacity }\end{array}$ & $\mathrm{INEF}_{\mathrm{B}}$ \\
\hline B9 & 4 & 4 & 2 & 0.50 & 152 & 1.62 & 1.20 & 0.86 & 1.41 & -0.9 & SI* & 0.71 \\
\hline B11 & 6 & 5 & 5 & 0.88 & 278 & 1.20 & 0.89 & 0.63 & 1.04 & 0.8 & NO & 0.96 \\
\hline B14 & 6 & 4 & 4 & 0.75 & 54 & 0.35 & 0.24 & 0.18 & 0.30 & -- & NO & 3.36 \\
\hline B18 & 6 & 5 & 4 & 0.79 & 1072 & 1.87 & 1.45 & 1.07 & 1.65 & 0 & SI & 0.61 \\
\hline B19 & 6 & 5 & 4 & 0.79 & 960 & 1.68 & 1.30 & 0.96 & 1.48 & -0.5 & SI* & 0.67 \\
\hline E1 & 4 & 5 & 2 & 0.54 & 71 & 0.77 & 0.63 & 0.50 & 0.70 & -0.6 & $\mathrm{NO}$ & 1.43 \\
\hline L1 & 6 & 5 & 5 & 0.88 & 170 & 1.59 & 1.29 & 1.02 & 1.43 & -1.4 & SI* & 0.70 \\
\hline M9 & 6 & 5 & 4 & 0.79 & 213 & 1.65 & 1.40 & 1.16 & 1.52 & 0.4 & SI & 0.66 \\
\hline M11 & 6 & 5 & 6 & 0.96 & 812 & 1.92 & 1.52 & 1.17 & 1.71 & 5.2 & SI & 0.58 \\
\hline M14 & 4 & 5 & 5 & 0.79 & 830 & 1.77 & 1.40 & 1.07 & 1.58 & 1.4 & SI & 0.63 \\
\hline M16 & 4 & 4 & 2 & 0.50 & 1080 & 2.10 & 1.66 & 1.27 & 1.87 & 1.9 & SI & 0.53 \\
\hline $\mathrm{Pa} 1$ & 2 & 2 & 2 & 0.33 & 845 & 3.10 & 2.47 & 1.90 & 2.77 & 2 & SI & 0.36 \\
\hline $\mathrm{Pa} 4$ & 0 & 0 & 1 & 0.08 & 630 & 1.77 & 1.39 & 1.06 & 1.57 & 0.8 & SI & 0.64 \\
\hline $\mathrm{R} 1$ & 4 & 5 & 5 & 0.79 & 1124 & 8.22 & 6.28 & 4.64 & 7.23 & 4.7 & SI & 0.14 \\
\hline $\mathrm{R} 2$ & 1 & 1 & 2 & 0.25 & 172 & 1.16 & 0.89 & 0.66 & 1.02 & \begin{tabular}{|c|}
-0.9 \\
\end{tabular} & NO & 0.98 \\
\hline R9 & 3 & 2 & 2 & 0.38 & 41 & 0.96 & 0.75 & 0.57 & 0.85 & -0.9 & $\mathrm{NO}$ & 1.17 \\
\hline $\mathrm{Cb} 2$ & 5 & 4 & 2 & 0.54 & 161 & 1.55 & 1.04 & 1.00 & 1.34 & \begin{tabular}{l|l}
0.9 \\
\end{tabular} & SI & 0.75 \\
\hline Ch5 & 5 & 4 & 4 & 0.71 & 235 & 2.62 & 1.89 & 1.31 & 2.25 & 0.7 & SI & 0.44 \\
\hline Ch6 & 5 & 4 & 4 & 0.71 & 330 & 3.68 & 2.66 & 1.83 & 3.16 & 0.1 & SI & 0.32 \\
\hline
\end{tabular}

RSC $=$ road-stream crossing; ADT = Average Daily Traffic; ADHT = Average Daily Heavy Traffic; $\mathrm{C}_{\mathrm{R}}=\mathrm{road}$ category; $\mathrm{I}_{\mathrm{EXP}}=$ Exposure Index; $\mathrm{MQ}_{\mathrm{S}}=$ maximum discharge drained through the bridge spans; $\mathrm{H}_{\mathrm{sp}}=$ average span height; $\mathrm{H}_{\mathrm{ov}}=$ overflow level. 
Furthermore, most major bridges (63\%) have sufficient capacity to drain discharges of up to a 500 year return period. According to the efficiency average degree $\left(\mathrm{AEF}_{\mathrm{B}}\right)$, the percentage of bridges with efficient drainage is about $74 \%$ (Table 6), and the remaining $26 \%$ is considered inefficient. Pontoons B14 and R9 and bridges R2, B11 and E1 show a higher level of inefficiency. The first is located upstream of the Nueva Cartagena housing estate, in Cartagena; R9 (the crossing of the Planas gully with road D-21) has no more bearing than low traffic on local tertiary roads has in this area. The intersection of the Miñarros Rambla (tributary of the Ramonete Rambla) and D-20 at bridge $\mathrm{R} 2$ records a low rate of exposure $(0.25)$, associated with a traffic intensity of under 250 vehicles per day.

Table 6. Estimate of hazard index in stream crossing bridges $\left(F H I_{B C}\right)$ depending on road exposure $\left(I_{E X P}\right)$ and inefficiency index for drainage structures $\left(I N E F_{B}\right)$.

\begin{tabular}{|l|c|c|c|c|c|c|c|c|c|}
\hline $\mathbf{R S C}$ & $\mathbf{A D T}$ & $\mathbf{A D H T}$ & $\mathbf{C}_{\mathbf{R}}$ & $\mathbf{I}_{\mathbf{E X P}}$ & $\begin{array}{c}\mathbf{M Q s} \\
\left(\mathbf{m}^{3} \mathbf{s}^{-1}\right)\end{array}$ & $\mathbf{A E F}_{\mathbf{B}}$ & $\mathbf{I N E F}_{\mathbf{B}}$ & $\mathbf{I N E F}_{\mathbf{B}}{ }^{*}$ & $\mathbf{F H I}_{\mathbf{B C}}$ \\
\hline B9 & 4 & 4 & 2 & 0.50 & 152 & 1.41 & 0.71 & 0.62 & 0.62 \\
\hline B11 & 6 & 5 & 5 & 0.88 & 278 & 1.04 & 0.96 & 0.96 & 1.68 \\
\hline B14 & 6 & 4 & 4 & 0.75 & 54 & 0.30 & 3.36 & 1.43 & 2.15 \\
\hline B18 & 6 & 5 & 4 & 0.79 & 1072 & 1.65 & 0.61 & 0.44 & 0.69 \\
\hline B19 & 6 & 5 & 4 & 0.79 & 960 & 1.48 & 0.67 & 0.56 & 0.88 \\
\hline E1 & 4 & 5 & 2 & 0.54 & 71 & 0.70 & 1.43 & 1.29 & 1.39 \\
\hline L1 & 6 & 5 & 5 & 0.88 & 170 & 1.43 & 0.70 & 0.60 & 1.04 \\
\hline M9 & 6 & 5 & 4 & 0.79 & 213 & 1.52 & 0.66 & 0.53 & 0.84 \\
\hline M11 & 6 & 5 & 6 & 0.96 & 812 & 1.71 & 0.58 & 0.40 & 0.76 \\
\hline M14 & 4 & 5 & 5 & 0.79 & 830 & 1.58 & 0.63 & 0.49 & 0.77 \\
\hline M16 & 4 & 4 & 2 & 0.50 & 1080 & 1.87 & 0.53 & 0.31 & 0.31 \\
\hline Pa1 & 2 & 2 & 2 & 0.33 & 845 & 2.77 & 0.36 & 0.06 & 0.04 \\
\hline Pa4 & 0 & 0 & 1 & 0.08 & 630 & 1.57 & 0.64 & 0.49 & 0.08 \\
\hline R1 & 4 & 5 & 5 & 0.79 & 1124 & 7.23 & 0.14 & 0.00 & 0.00 \\
\hline R2 & 1 & 1 & 2 & 0.25 & 172 & 1.02 & 0.98 & 0.98 & 0.49 \\
\hline R9 & 3 & 2 & 2 & 0.38 & 41 & 0.85 & 1.17 & 1.15 & 0.86 \\
\hline Cb2 & 5 & 4 & 2 & 0.54 & 161 & 1.34 & 0.75 & 0.68 & 0.74 \\
\hline Ch5 & 5 & 4 & 4 & 0.71 & 235 & 2.25 & 0.44 & 0.16 & 0.23 \\
\hline Ch6 & 5 & 4 & 4 & 0.71 & 330 & 3.16 & 0.32 & 0.03 & 0.04 \\
\hline
\end{tabular}

RSC $=$ road-stream crossing; ADT $=$ Average Daily Traffic, ADHT $=$ Average Daily Heavy Traffic; $\mathrm{C}_{\mathrm{R}}=$ road category; $\mathrm{I}_{\mathrm{EXP}}=$ Exposure Index, $\mathrm{MQ}_{\mathrm{S}}=$ drainage capacity of bridge spans;

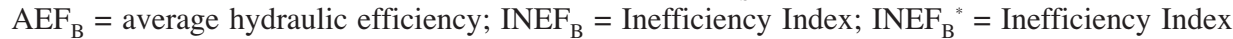
adjusted by a weighting factor with potential function; $\mathrm{FHI}_{\mathrm{BC}}=$ Flood Hazard Index for bridge crossings. Grey colors refer to categories of Table 2. 
However, crossing E1 of the Portman-Cartagena road located over the Escombreras Rambla had a greater traffic intensity, both heavy and light traffic, which made its low hydraulic efficiency a crucial hazard factor. The last case is B11, classified as a crossing with critical drainage efficiency, located on the AP-7 highway, just in the west peripheral sector of the town of Cartagena, downstream from the confluence of the Ladrillar Rambla with the Benipila Rambla. This is one of the most conflictive points, given the high degree of exposure and average daily traffic $(>7500$ vehicles per day). Thus, although the revised degree of inefficiency was lower than 1 , it was very close to this value $\left(\mathrm{INEF}_{\mathrm{B}}{ }^{*}=0.96\right)$. Taking into account its high exposure index, it can be considered a high hazard crossing $\left(\mathrm{FHI}_{\mathrm{BC}}=1.68\right)$. The road-stream junctions B14 (the Benipila Rambla with the urban road), E1 (the Escombreras Rambla with the tertiary regional Portmán-Cartagena road) and L1 (the Lorentes Rambla with N-332-1 Cartagena-Mazarrón) also exceeded the threshold of the high flood hazard $\left(\mathrm{FHI}_{\mathrm{BC}} \geq 1\right)$ (Table 6). Of those crossings classified as being a high hazard, only L1 had drainage works with an appropriate capacity to drain 200-year floods.
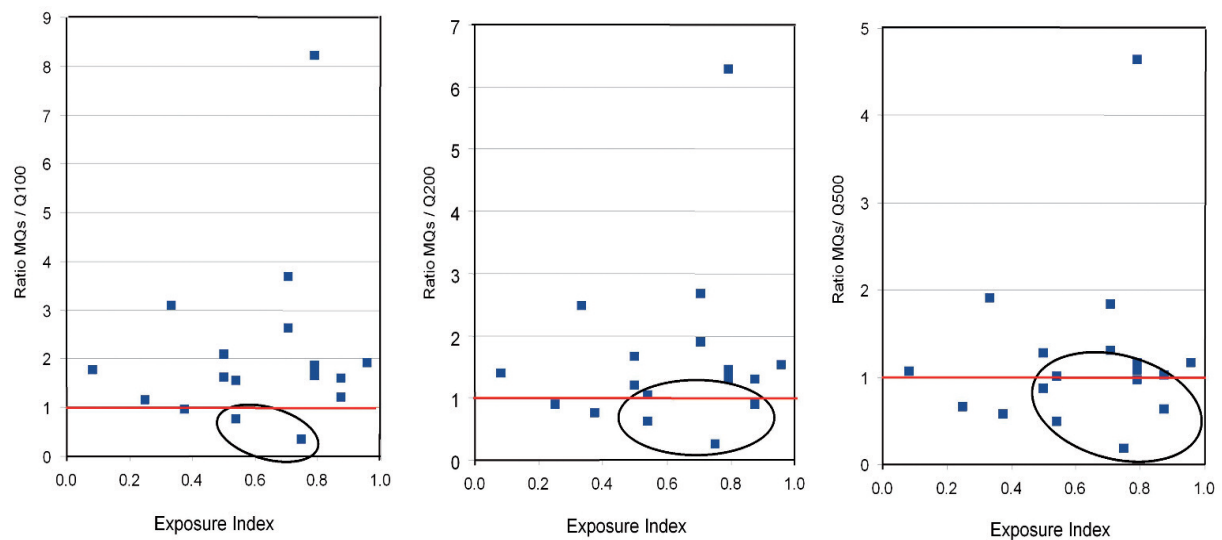

Figure 4. Ratio between bridge flow capacity and discharges for different return periods $(M Q s / Q x)$ versus exposure index $\left(I_{E X P}\right)$. The dots inscribed in circles represent the most problematic bridges, with an insufficient drainage capacity and a high exposure index.

Fig. 4 shows the ratios between drainage capacity of the bridge spans and estimated discharges for different return periods versus the exposure index values. Just two bridges have high levels of exposure and insufficient capacity for draining 100year floods. However, four crossings show high flood hazard for ratios $M Q s / Q_{200}<1$ and seven for ratios $M Q s / Q_{500}<1$. 


\subsection{Hydromorphological hazard in the rambla reaches crossed by bridges}

The most common geomorphic effects of floods are bed scouring and sedimentation which appear after them in the main channel and floodplains. Channel planform changes, avulsions and lateral movements of channel banks caused by extreme flash-floods are morphological adjustments which affect the overall fluvial system. Smaller-scale changes are developed into the channel at near-bankfull or lower flows, from bank erosion to local bed variations associated with mobility of alluvial bed forms (dunes, bars, etc.). Most of these adjustments are superficial changes easily observable in situ. However, the bed scouring during the rising hydrograph stage is more difficult to detect. This is problematical inasmuch as it may endanger the stability of the exposed hydraulic structures.

The contraction of flow due to a bridge can be caused by either a natural decrease in flow area of the stream channel or by abutments projecting into the channel and/or the piers blocking a large portion of the flow area. Contraction can also be caused by the approaches to a bridge cutting off the floodplain flow (Arneson and Abt, 1999; US Department of Transportation, 2001). This can cause clear water scour on a setback portion of a bridge section and/or a relief bridge because the floodplain flow does not normally transport significant concentrations of bed material sediments (Neill, 1973). In semi-arid regions, where the floodplain waters provide a greater volume of sediment upon reaching the main channel, this is dominated by dynamic scour, a process involving both deposition and erosion. In addition, local scour at abutments may well be greater due to the floodplain flow returning to the main channel at the end of the abutment.

The height of a granular bed decreases during the rising limb of a flood hydrograph, due to increases in stream power and sediment transport capacity. At the falling limb transitory bed pools are filled by sediments arriving from upstream. This process, known in geomorphology and river-engineering as "general transitory scouring", can end up having serious consequences: first, the channel banks become unstable, allowing the migration of the main bed inside the floodplain (Martín Vide et al., 1993). On the other hand, the bed experiences a momentary lowering of its base which can affect infrastructure installations. As a result, channelling works, protection or anchors are in danger of being destroyed, like the drainage works (bridges, buried conduits, etc). Analysis of this process is crucial for assessing the hydromorphological hazard degree on bridges crossing ephemeral streams (Conesa García and García Lorenzo, 2011). Though the most important damage is generally produced in the rising limb of a flash-flood hydrograph, the transitory scouring is only one part of the overall bed erosion and the potential damages caused by a watercourse in the long term are really determined by the general bed erosion (net erosion amount over time) (Martín Vide, 1997).

Tables 7 to 9 show the values of transitory scouring estimated in the chosen bridge crossings for return periods of 100, 200 and 500 years. Based on these results, the general transitory scouring calculated for 100 -year floods exceeds $0.3 \mathrm{~m}$ in more than $66 \%$ of cases, and $0.6 \mathrm{~m}$ in $13 \%$ of them. 
Table 7. Critical velocity values and general transitory scouring estimated for 100-year floods in the studied road-stream crossings.

\begin{tabular}{|c|c|c|c|c|c|c|c|c|}
\hline RSC & $\mathbf{y}_{\mathbf{0}}(\mathbf{m})$ & $\mathbf{A}\left(\mathbf{m}^{2}\right)$ & $\mathbf{D}_{\mathbf{8 4}}(\mathbf{m})$ & $\mathbf{V}_{\mathbf{c}}\left(\mathbf{m ~ s}^{-1}\right)$ & $\mathbf{Q}_{\left(\mathbf{m}^{3} \mathbf{s}^{-1}\right)}$ & $\mathbf{A}^{\prime}\left(\mathbf{m}^{2}\right)$ & $\mathbf{y}_{\mathbf{0}}{ }^{\prime}(\mathbf{m})$ & $\mathbf{G T S}(\mathbf{m})$ \\
\hline B9 & 1.29 & 47.73 & 0.02190 & 1.66 & 93.9 & 56.54 & 1.53 & 0.24 \\
\hline B11 & 1.59 & 120.80 & 0.01530 & 1.53 & 231.4 & 151.66 & 2.00 & 0.41 \\
\hline E1 & 1.25 & 54.00 & 0.01530 & 1.47 & 92.3 & 62.97 & 1.46 & 0.21 \\
\hline L1 & 1.57 & 51.81 & 0.01960 & 1.65 & 107.0 & 64.71 & 1.96 & 0.39 \\
\hline M9 & 0.72 & 68.00 & 0.00910 & 1.12 & 129.0 & 114.72 & 1.21 & 0.49 \\
\hline M11 & 1.55 & 169.00 & 0.03180 & 1.94 & 422.0 & 217.64 & 2.00 & 0.45 \\
\hline M14 & 1.67 & 197.00 & 0.02060 & 1.70 & 468.8 & 275.98 & 2.34 & 0.67 \\
\hline M16 & 2.39 & 272.46 & 0.00930 & 1.38 & 515.5 & 372.65 & 3.27 & 0.88 \\
\hline Pa1 & 1.02 & 107.00 & 0.03150 & 1.80 & 272.7 & 151.21 & 1.45 & 0.42 \\
\hline Pa4 & 0.59 & 26.55 & 0.01330 & 1.23 & 37.9 & 30.70 & 0.68 & 0.09 \\
\hline R1 & 1.07 & 64.00 & 0.01820 & 1.51 & 136.8 & 90.39 & 1.51 & 0.44 \\
\hline R2 & 1.29 & 66.00 & 0.02470 & 1.73 & 148.5 & 85.91 & 1.68 & 0.39 \\
\hline R9 & 1.43 & 19.00 & 0.03380 & 1.95 & 42.8 & 21.92 & 1.65 & 0.22 \\
\hline Cb2 & 1.62 & 70.2 & 0.02410 & 1.78 & 154.9 & 86.98 & 2.01 & 0.39 \\
\hline Ch5 & 1.08 & 38.90 & 0.03310 & 1.85 & 89.7 & 48.48 & 1.35 & 0.27 \\
\hline
\end{tabular}

RSC = road-stream crossing; $\mathrm{y}_{0}=$ initial water depth; $\mathrm{A}=$ initial wetted cross-section area; $\mathrm{D}_{84}=$ particle size corresponding to percentile 84 of the total sample weight; $\mathrm{Q}=$ discharge; $\mathrm{V}_{\mathrm{c}}=$ critical velocity; $\mathrm{y}_{0}{ }^{\prime}=$ flow level at maximum scouring depth; $\mathrm{A}^{\prime}=$ new cross section for the critical velocity; GTS $=$ general transitory scouring.

The highest values for $\mathrm{Q}_{100}$ were registered in M14 and M16 (GTS of 0.67 and $0.88 \mathrm{~m}$ respectively). M14 is the Moreras Rambla crossing road N-332-1 in the close surroundings of Mazarrón (Fig. 3) and M16 the intersection of Moreras Rambla with D-6 (local tertiary road), which links the Port of Mazarrón with Bolnuevo. The closest reach upstream of the M14 crossing (M14*) has a very active granular bed, made up of highly unstable deposits. It is formed by cross-linked bars of silt and sands interspersed with gravels and pebbles. The central longitudinal bar is poorly vegetated by scrubs, and only its platform head has certain stability (Fig. 3). During extreme flood events these alluvial bars can be completely deleted, moved downstream or secondary bedforms may be generated.

The stream reach crossed by bridge M16 has a fine-textured bed (silt and sand) with a granular structure and a flat bottom (Fig. 3). Only the basement of the lateral piers and abutment blocks have been settled for their protection. General transitory scouring on this reach was calculated ignoring the vegetation cover, whose density varies depending on the season and planning of bed cleaning tasks. 
The transitory scour depth estimated for peak discharges of 200-year return periods normally exceeds $1 \mathrm{~m}$ (Table 8). This is considered a minimum critical threshold, which should be taken into account in the design of drainage works such as that existing in the studied area. Under such conditions, almost $47 \%$ of channel reaches equipped with bridges record transitory scouring rates of over $0.6 \mathrm{~m}$. However, the critical threshold established as particularly dangerous in the existing technical regulation in this regard (ACA, 2011) corresponds to the predictable transitory bed erosion for 500-year floods (Table 9). That is also expressed in the technical document written by the Agència Catalana de l'Aigua (ACA, 2004) for the design of crossing works (construction works in rural roads and its modifications, fords, etc.) and conduit crossings or pipes under riverbeds.

For 500-year flood peak discharges transitory scour depth is higher than $0.9 \mathrm{~m}$ in seven channel cross-sections upstream of the bridge crossings (Cb2, R1, R2, Pa1, M14, M16 and B11), reaching 1.24 and $1.84 \mathrm{~m}$ in M14 and M16 respectively.

Table 8. Critical velocity values and general transitory scouring estimated for 200-year floods in the studied road-stream crossings.

\begin{tabular}{|l|c|c|c|c|c|c|c|c|}
\hline \multicolumn{1}{|c|}{$\mathbf{R S C}$} & $\mathbf{y}_{\mathbf{0}}(\mathbf{m})$ & $\mathbf{A}\left(\mathbf{m}^{\mathbf{2}}\right)$ & $\mathbf{D}_{\mathbf{8 4}}(\mathbf{m})$ & $\mathbf{V}_{\mathbf{c}}\left(\mathbf{m ~ s}^{\mathbf{1}}\right)$ & $\mathbf{Q}\left(\mathbf{m}^{3} \mathbf{s}^{-1}\right)$ & $\mathbf{A}^{\prime}\left(\mathbf{m}^{2}\right)$ & $\mathbf{y}_{\mathbf{0}}{ }^{(\mathbf{m})}$ & $\mathbf{G T S}(\mathbf{m})$ \\
\hline B9 & 1.53 & 58.14 & 0.02190 & 1.71 & 126.2 & 73.86 & 1.94 & 0.41 \\
\hline B11 & 1.67 & 145.00 & 0.01530 & 1.54 & 312.8 & 203.34 & 2.34 & 0.67 \\
\hline E1 & 1.41 & 60.00 & 0.01530 & 1.50 & 113.0 & 75.56 & 1.78 & 0.37 \\
\hline L1 & 1.77 & 58.41 & 0.01960 & 1.69 & 131.7 & 78.07 & 2.37 & 0.60 \\
\hline M9 & 1.28 & 81.00 & 0.00910 & 1.24 & 152.0 & 122.82 & 1.94 & 0.66 \\
\hline M11 & 1.81 & 202.72 & 0.03180 & 1.99 & 533.9 & 268.33 & 2.40 & 0.59 \\
\hline M14 & 1.91 & 223.00 & 0.02060 & 1.74 & 593.6 & 341.72 & 2.93 & 1.02 \\
\hline M16 & 2.72 & 315.52 & 0.00930 & 1.41 & 651.2 & 460.71 & 3.97 & 1.25 \\
\hline Pa1 & 1.45 & 123.00 & 0.03150 & 1.91 & 342.4 & 179.13 & 2.11 & 0.66 \\
\hline Pa4 & 0.7 & 31.50 & 0.01330 & 1.27 & 49.8 & 39.21 & 0.87 & 0.17 \\
\hline R1 & 1.3 & 79.00 & 0.01820 & 1.56 & 179.1 & 114.56 & 1.89 & 0.59 \\
\hline R2 & 1.49 & 75.00 & 0.02470 & 1.77 & 193.1 & 109.06 & 2.17 & 0.68 \\
\hline R9 & 1.58 & 22.00 & 0.03380 & 1.99 & 54.4 & 27.40 & 1.97 & 0.39 \\
\hline Cb2 & 1.82 & 87.2 & 0.02410 & 1.82 & 208.3 & 114.72 & 2.39 & 0.57 \\
\hline Ch5 & 1.31 & 47.16 & 0.03310 & 1.91 & 124.1 & 64.95 & 1.80 & 0.49 \\
\hline
\end{tabular}

RSC = road-stream crossing; $\mathrm{y}_{0}$, initial water depth; $\mathrm{A}=$ initial wetted cross-section area; $\mathrm{D}_{84}=$ particle size corresponding to percentile 84 of the total sample weight; $\mathrm{Q}=\operatorname{discharge} ; \mathrm{V}_{\mathrm{c}}=$ critical velocity; $\mathrm{y}_{0}{ }^{\prime}=$ flow level at maximum scouring depth; $\mathrm{A}^{\prime}=$ new cross section for the critical velocity; GTS = general transitory scouring. 
Table 9. Critical velocity values and general transitory scouring estimated for 500-year floods in the studied road-stream crossings.

\begin{tabular}{|l|r|r|r|r|r|r|c|c|}
\hline $\mathbf{R S C}$ & $\mathbf{y}_{\mathbf{0}}(\mathbf{m})$ & $\mathbf{A}\left(\mathbf{m}^{\mathbf{2}}\right)$ & $\mathbf{D}_{\mathbf{8 4}}(\mathbf{m})$ & $\mathbf{V}_{\mathbf{c}}\left(\mathbf{m ~ s}^{\mathbf{1}}\right)$ & $\mathbf{Q}\left(\mathbf{m}^{3} \mathbf{s}^{-1}\right)$ & $\mathbf{A}^{\prime}\left(\mathbf{m}^{\mathbf{2}}\right)$ & $\mathbf{y}_{\mathbf{0}}{ }^{\prime}(\mathbf{m})$ & $\mathbf{G T S}(\mathbf{m})$ \\
\hline B9 & 1.81 & 72.40 & 0.02190 & 1.76 & 176.4 & 100.39 & 2.51 & 0.70 \\
\hline B11 & 1.76 & 183.00 & 0.01530 & 1.55 & 439.5 & 283.21 & 2.72 & 0.96 \\
\hline E1 & 1.62 & 68.00 & 0.01530 & 1.53 & 143.3 & 93.63 & 2.23 & 0.61 \\
\hline L1 & 2.03 & 66.99 & 0.01960 & 1.73 & 165.9 & 96.12 & 2.91 & 0.88 \\
\hline M9 & 1.43 & 90.00 & 0.00910 & 1.26 & 183.0 & 145.16 & 2.31 & 0.88 \\
\hline M11 & 1.98 & 241.56 & 0.03180 & 2.02 & 695.4 & 344.31 & 2.82 & 0.84 \\
\hline M14 & 2.21 & 279.00 & 0.02060 & 1.78 & 774.1 & 434.92 & 3.45 & 1.24 \\
\hline M16 & 3.19 & 370.04 & 0.00930 & 1.45 & 847.2 & 583.66 & 5.03 & 1.84 \\
\hline Pa1 & 1.68 & 145.00 & 0.03150 & 1.96 & 444.3 & 226.81 & 2.63 & 0.95 \\
\hline Pa4 & 0.84 & 37.80 & 0.01330 & 1.31 & 67.4 & 51.48 & 1.14 & 0.30 \\
\hline R1 & 1.52 & 94.00 & 0.01820 & 1.60 & 242.4 & 151.07 & 2.44 & 0.92 \\
\hline R2 & 1.86 & 93.00 & 0.02470 & 1.84 & 260.2 & 141.62 & 2.83 & 0.97 \\
\hline R9 & 1.77 & 27.00 & 0.03380 & 2.02 & 71.4 & 35.29 & 2.31 & 0.54 \\
\hline Cb2 & 2.15 & 109.5 & 0.02410 & 1.87 & 292.1 & 156.47 & 3.07 & 0.92 \\
\hline Ch5 & 1.64 & 59.04 & 0.03310 & 1.98 & 180.0 & 90.75 & 2.52 & 0.88 \\
\hline
\end{tabular}

RSC = road-stream crossing; $\mathrm{y}_{0}=$ initial water depth; $\mathrm{A}=$ initial wetted cross-section area; $\mathrm{D}_{84}=$ particle size corresponding to the 84th percentile of the total sample weight; $\mathrm{Q}=$ discharge; $\mathrm{V}_{\mathrm{c}}=$ critical velocity; $\mathrm{y}_{0}{ }^{\prime},=$ flow level at maximum scouring depth; $\mathrm{A}^{\prime}=$ new cross section for the critical velocity; GTS = general transitory scouring.

Despite the high transitory scour rates obtained for these limey-sand beds, the net bed erosion does not seem to be significant; in some cases even sedimentation predominates over erosion (Conesa-García and García-Lorenzo, 2010). Most of them are located in the lower reaches of the ramblas (e.g. Cb2, B11, M14 and M16), characterized by vertical accretion processes. After flooding, in these cross-sections, granular beds tend to recover the original height, thus giving the impression that there was no erosion, whereas in fact some structures placed there had suffered important damage or had been about to fail. But this process does not necessarily have to be a closed-loop, and the final level of the bed can be found below the initial one, resulting in a net or residual scour. The Geomorphological Hazard Index $\left(\mathrm{GHI}_{\mathrm{BC}}\right)$, deducted from the granular bed susceptibility to incision, the critical velocity and the general transitory scouring, reflects the above-mentioned results to a large extent.

More than $50 \%$ of the bridge crossings show a high $\mathrm{GHI}_{\mathrm{BC}}$ (Table 10). One of them is especially dangerous (M16) $\left(\mathrm{GHI}_{\mathrm{BC}}>1.25\right)$, due to bed erodibility and to the great flow power developed by the Moreras Rambla bursting its banks in its medium-low reach. In this case, bed armouring is very limited while bed susceptibility rate to incision acquires highly significant values. Both factors, together with high velocity 
and transitory scour rates achieved in large floods $\left(\mathrm{GTS}_{500}=1.84 \mathrm{~m}\right)$, justify the geomorphological hazard level represented by $\mathrm{GHI}_{\mathrm{BC}}$ for this cross-section. In other crossings where the bed armouring rates are high $(\mathrm{Ar}>5)$ and the sediments are resistant to erosion (GSI < 0.25), the high hazard attributed to the weighted average transitory scouring $\left(\mathrm{GTS}^{*}\right)$ corresponds to a moderate $\mathrm{GHI}_{\mathrm{BC}}$. For such cases, stream instability countermeasures to monitor flow and minimize bridge stability risks are not required.

Table 10. Values of variables used for calculating Geomorphological Hazard Index $\left(G H I_{B C}\right)$.

\begin{tabular}{|l|c|c|c|c|c|c|c|c|c|}
\hline RSC & Ar & GSI & $\begin{array}{c}\mathbf{V}_{\mathbf{c}}{ }^{*} \\
\left(\mathbf{m ~ s}^{-1}\right)\end{array}$ & $\begin{array}{c}\mathbf{G T S}_{\mathbf{1 0 0}} \\
(\mathbf{m})\end{array}$ & $\begin{array}{c}\mathbf{G T S}_{\mathbf{2 0 0}} \\
(\mathbf{m})\end{array}$ & $\begin{array}{c}\mathbf{G T S}_{\mathbf{5 0 0}} \\
(\mathbf{m})\end{array}$ & $\begin{array}{c}\mathbf{G T S}^{*} \\
(\mathbf{m})\end{array}$ & $\begin{array}{c}\mathbf{U}_{\text {cr }}^{*} \\
\mathbf{G T S}^{*}\end{array}$ & GHI $_{\mathbf{B C}}$ \\
\hline B9 & 3.99 & 0.563 & 1.69 & 0.24 & 0.41 & 0.70 & 0.39 & 0.67 & 0.62 \\
\hline B11 & 2.79 & 0.787 & 1.53 & 0.41 & 0.67 & 0.96 & 0.60 & 0.92 & 0.85 \\
\hline E1 & 2.79 & 0.787 & 1.49 & 0.21 & 0.37 & 0.61 & 0.34 & 0.51 & 0.65 \\
\hline L1 & 3.57 & 0.650 & 1.68 & 0.39 & 0.60 & 0.88 & 0.56 & 0.94 & 0.79 \\
\hline M9 & 2.76 & 0.874 & 1.18 & 0.49 & 0.66 & 0.88 & 0.63 & 0.74 & 0.81 \\
\hline M11 & 5.80 & 0.078 & 1.97 & 0.45 & 0.59 & 0.84 & 0.58 & 1.14 & 0.61 \\
\hline M14 & 3.76 & 0.613 & 1.73 & 0.67 & 1.02 & 1.24 & 0.88 & 1.51 & 1.06 \\
\hline M16 & 2.81 & 0.869 & 1.41 & 0.88 & 1.25 & 1.84 & 1.21 & 1.70 & 1.28 \\
\hline Pa1 & 5.75 & 0.095 & 1.86 & 0.42 & 0.66 & 0.95 & 0.61 & 1.13 & 0.61 \\
\hline Pa4 & 3.05 & 0.797 & 1.26 & 0.09 & 0.17 & 0.30 & 0.16 & 0.21 & 0.50 \\
\hline R1 & 3.32 & 0.698 & 1.55 & 0.44 & 0.59 & 0.92 & 0.60 & 0.93 & 0.81 \\
\hline R2 & 4.51 & 0.444 & 1.77 & 0.39 & 0.68 & 0.97 & 0.59 & 1.05 & 0.75 \\
\hline R9 & 6.16 & 0.001 & 1.98 & 0.22 & 0.39 & 0.54 & 0.33 & 0.66 & 0.31 \\
\hline Cb2 & 3.80 & 0.542 & 1.81 & 0.39 & 0.57 & 0.92 & 0.57 & 1.03 & 0.78 \\
\hline Ch5 & 4.40 & 0.470 & 1.90 & 0.27 & 0.49 & 0.88 & 0.47 & 0.90 & 0.68 \\
\hline
\end{tabular}

$\mathrm{RSC}=$ road-stream crossing; $\mathrm{Ar}=$ bed armouring rate; $\mathrm{GSI}=$ Granular bed susceptibility to incision; $\mathrm{V}_{\mathrm{c}}=$ critical velocity; GTS $\mathrm{x}=$ General transitory scour rates for $\mathrm{x}$ return period; $\mathrm{V}_{\mathrm{c}} *$ and GTS* $=$ Weighted averages of both variables calculated according to the occurrence probability of GTS rates attributable to 100, 200 and 500-years floods.

Some field evidence of overflow and morphological effects from recent extreme floods (Conesa-García et al., 2010) corroborates these findings. The destructive effects of the floods on 23rd October 2000 and 28th September 2012 are two clear examples (Fig. 5). On both dates, several vital bridges and large stretches of roads were washed away in flash floods caused by heavy rains in Southeast Spain. Huge storms, with precipitation higher than $120 \mathrm{~mm}$ in a few hours reached large headwaters causing ramblas to overflow. Over five bridges in areas of Murcia and Almería failed due to the scour of foundation material. In particular, two important bridges were destroyed on the AP-7 and A-7 Mediterranean highways. The bridge of the A-7 over the Béjar Rambla (Fig. 5: 2a) was located downstream an aggregate load and it led to a slow lowering of 
the bed and progressive channel degradation. Over recent decades this ephemeral stream has became deficient in sediment supply due to sediment being removed upstream, so bed scouring around bridge abutments or piers has increased. Finally, new scour holes of up to more than two meters of depth were scooped out during the flood of 28 th October 2012, endangering the integrity of the structure. Foundations of piers were totally exposed and the bridge failed (Fig. 5: 2b). On the same date the foundation of the Puerto-Lumbreras bridge was also dug up by flooding of the Nogalte Rambla, which reached a peak discharge of higher than $700 \mathrm{~m}^{3}$ and a GTS of about $1.4 \mathrm{~m}$ (Fig. 5: 3b).
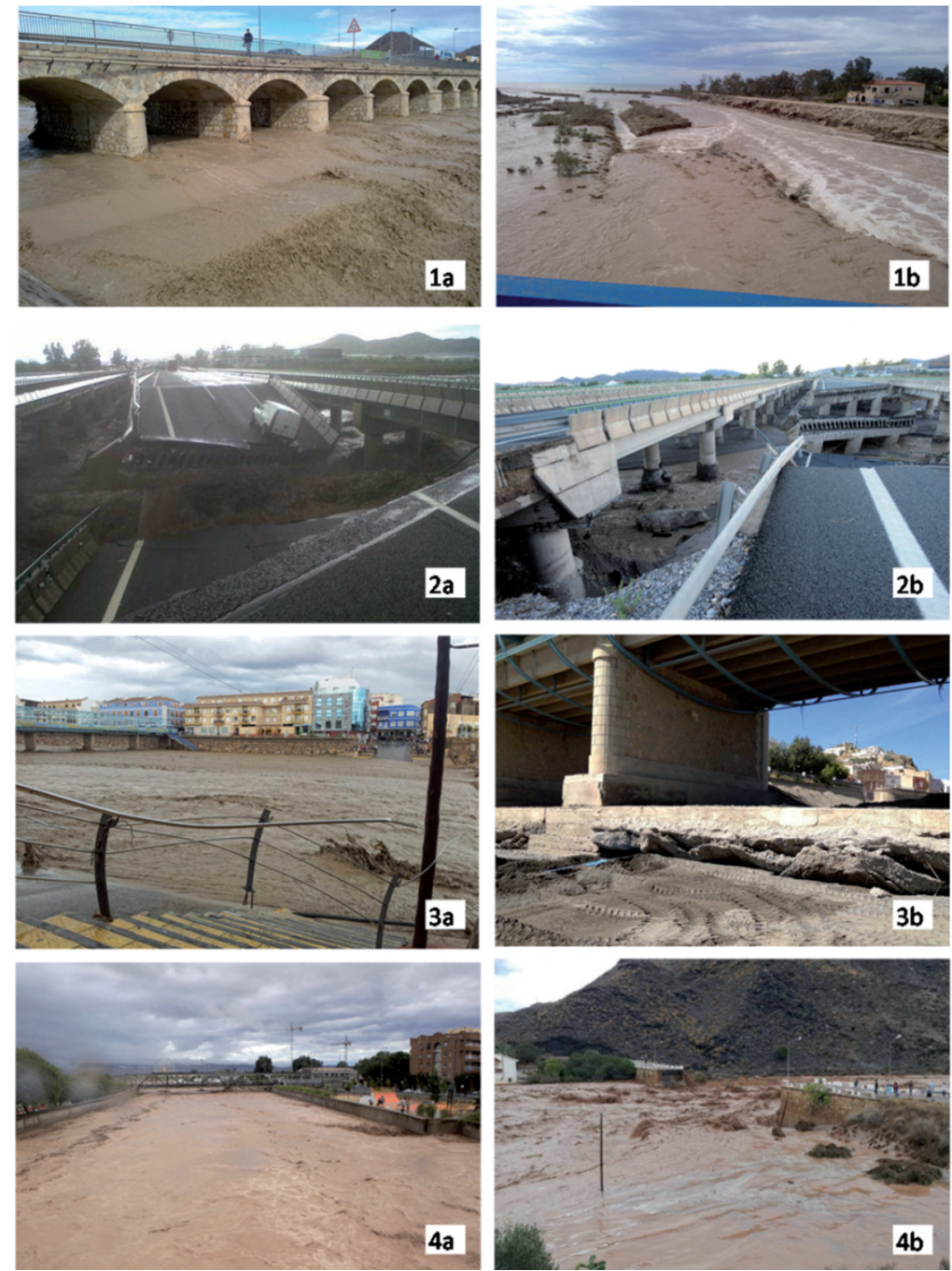

Figure 5. Flooding by ephemeral channels on September 28th, 2012, affecting bridge crossings in South East Spain. Scour holes downstream of crossings M14 (1a) and M16 (1b); Failure of the bridge due to scour at their foundations on the A-7 over the Béjar Rambla (2a and $2 b$ ); Nogalte Rambla at the point where it passes through Puerto Lumbreras before (3a) and after the flood ( $3 b$ ); Guadalentin

Rambla at its pass through Lorca (4a); Old bridge destroyed by flooding in Lobos Rambla (4b). 
At bridge openings, contraction scour occurred in many cases, especially at crosssections in which the opening was much narrower than the channel upstream the bridge. Degradation scour took place upstream and downstream bridges over large areas. High channel instability resulting in rambla erosion and changing angles-ofattack contributed to bridge scour. Debris also had a substantial impact on bridge scour in several ways. For example, a build-up of material under the bridge of Lobos reduced the size of the waterway causing contraction scour in its channel (Fig. 5: 4b). A high bedload was already being transported into the contracted bridge section from upstream of the approach section. In addition, debris deflected the water flow, changing the angle of attack, and increasing local scour. It resulted in a significant live-bed contraction scour, in which the critical velocity of the bed material $\left(\mathrm{V}_{\mathrm{c}} \approx 1.74 \mathrm{~m} \mathrm{~s}^{-1}\right)$ was much lower than the mean velocity at the approach section $\left(\mathrm{V}=6.3 \mathrm{~m} \mathrm{~s}^{-1}\right)$. The road embankments at the proximity of the bridge caused all the overbank flow to be forced into the main channel; the bridge abutments were projected into the main channel and the bridge piers blocked a significant portion of the flow area. During flooding, although the foundations of certain single-span bridges did not suffer damage, flow around abutments and approach embankments and the associated scour at those locations strongly influenced scour at the piers into the main channel.

Although just in a few crossings the hydraulic capacity was exceeded, the bridge inlets often experienced the strong effects of a high bedload deposited upstream. In most RSCs the torrential flow was enough to move and displace considerable quantities of material. At the overflow stage, the smaller bridges and pontoons lost their usefulness as they become blocked with woody debris and sediment, contributing to road flooding and putting the crossing structure at risk. The most critical situations caused by sediment accumulation, bed instability, and the mobility of coarse particles occurred in overflow streams, whose hydraulic ratio and flow velocity significantly increased potential build-up. In ephemeral streams with a steep slope $(>2.5 \%)$, such as the Nogalte and Lobos ramblas, the floodwaters developed high flow velocities, which moved very coarse particles. Since the sediment source areas are near to crossings and are especially productive, these channels constitute a serious problem for drainage systems. The great quantity of material transported during the flood, including driftwood and floating logs, increased the rhythm of obstruction in small bridge spans. Then, the pontoons and low bridges lost usefulness and were partly blocked raising the water flow level. Additionally, it must not be forgotten that in such cases, the morphological adjustment of the channel itself in search of its dynamic equilibrium generates a significant hazard, since it increases the level of exposure to the mobilized bedload (Venditti et al., 2010).

The mean value of unit bedload discharge calculated upstream from the bridges $\left(10.48 \cdot 10^{-3} \mathrm{~m}^{-2} \mathrm{~s}^{-1}\right)$ did mask appreciable variations according to cases. For instance, the reaches affecting crossings B11 (AP-7 with Benipila Rambla) and M16 (D-6 with Moreras Rambla) recorded high bedload rates per unit of width $\left(0.014\right.$ to $\left.0.02 \mathrm{~m}^{2} \mathrm{~s}^{-1}\right)$ under peak discharges of 390 and $520 \mathrm{~m}^{3} \mathrm{~s}^{-1}$ respectively. However, upstream of crossing R9 (D-21 over a tributary gully of the Ramonete Rambla) the unit bedload 
transport rate was $4 \cdot 10^{-5} \mathrm{~m}^{2} \mathrm{~s}^{-1}$, which represents relative bed stability and less mobility of sediments. Very high rates, above the mean $\left(\geq 0.008 \mathrm{~m}^{2} \mathrm{~s}^{-1}\right)$, have been registered in the reaches of the L1, M9, M14, R1, R2 and Cb2 crossings. Moreover in these cases it has been observed that increases in channel width immediately upstream of the bridge inlet promote the accumulation of both woody debris and sediment at the inlet. The same morphological effect has been confirmed in gullies locally widened before bridge culverts that have high hydraulic shear stress and unit bedload discharge (Furniss et al., 2002).

Under such circumstances, the potential for partial bridge obstruction associated with a significant flow deflection and live-bed contraction scour at the inlet has proved to be a clear indicator of a hydromorphological hazard.

\section{Conclusions}

The proposed indices $\mathrm{FHI}_{\mathrm{BC}}$ and $\mathrm{GHI}_{\mathrm{BC}}$ represent a methodological approach to determine the hazard associated with flooding in bridges crossing ephemeral channels. The implementation of these indices using hydrological, hydraulic and morphological criteria and exposure factors can be useful for the local authorities and institutions involved in the management of this type of hazard. The exposure parameters, obtained through counting vehicles and the roadway inventory, and the inefficiency index of the drainage works have easily been integrated in the $\mathrm{FHI}_{\mathrm{BC}}$ index. The greatest challenge was to consider hydraulic and hydromorphological variables in the elaboration of the $\mathrm{FHI}_{\mathrm{BC}}$ index. As these are dry channels facing severe flash-floods in a few hours for most of the year, and they have no gauging stations, some of the basic parameters of such an index had to be estimated through empirical methods based on numerous field data. In fact, the final accuracy of the results greatly depends on the quality of bedmaterial sampling and the hydraulic geometry measures.

The $\mathrm{FHI}_{\mathrm{BC}}$ index integrates useful information concerning the infrastructures exposed to flood hazards (category of road and traffic intensity) and it is an indicator $\left(\mathrm{AEF}_{\mathrm{B}}\right)$ for assessing the average efficiency of bridges crossing these types of channels. According to this index, $26 \%$ of bridge crossings have been classified as inefficient, while the rest $(74 \%)$ had a moderately efficient drainage.

The results suggest that the Geomorphological Hazard Index is representative of scouring and bedload capacity at the bridge crossings. High values of $\mathrm{GHI}_{\mathrm{BC}}$ were found in more than half of the studied crossings. The variables $\mathrm{V}_{\mathrm{c}}$ (critical velocity) and GTSx (general transitory bed scouring for $x$ return period), which are part of this index, can be considered good indicators for evaluating scour hazard under local flow conditions. These give an idea of the momentary bed degradation and scour depth achieved around piers or abutments during floods of different magnitudes. Critical values of GTS for 100 and 200-year floods were obtained in $13 \%$ and $47 \%$ of crossings respectively. In these cases, stream instability countermeasures could be incorporated into the road-stream crossing system to monitor, control, inhibit, change, delay, or minimize stream and bridge stability problems. A countermeasure for scour critical 
bridges and unknown foundations could also be the monitoring of a bridge during and/or after a flood event. In the crossings with the highest GTS values (i.e. GTS $_{200}>$ $1.25 \mathrm{~m}$ ), protection such as riprap and bed roughness increase are really necessary to reduce the risk of scour failure.

Finally, a detailed cartography of flood hazards in bridges crossing ephemeral streams can be generated from the combined use of both indexes $\left(\mathrm{FHI}_{\mathrm{BC}}\right.$ and $\left.\mathrm{GHI}_{\mathrm{BC}}\right)$ in order to prevent risk situations and improve the design of drainage works.

\section{Acknowledgements}

This paper was carried out as part of the research project 02955/PI/05 framework, "Processes of natural hazards associated with fluvial torrential systems in Mediterranean environments. Application to the southern coast in Murcia (Spain)", financed by Fundación SENECA, A Regional Agency of Science and Technology in Murcia.

\section{References}

AASHTO 1999. AASHTO Maintenance Manual: The Maintenance and Management of Roadways and Bridges. American Association of State Highway and Transportation Officials.

AASHTO 2003a. AASHTO Manual for Condition Evaluation and Load and Resistance Factor Rating (LRFR) of Highway Bridges. American Association of State Highway and Transportation Officials.

AASHTO 2003b. AASHTO Steel Guide Specifications for Horizontally Curved Steel Girder Highway Bridges. American Association of State Highway and Transportation Officials.

AASHTO 2004. AASHTO LRFD Bridge Design Specifications. American Association of State Highway and Transportation Officials, 3rd Edition.

ACA (Agència Catalana de l'Aigua) 2004. Recomanacions tècniques per al disseny d'infraestructures que interfereixen amb l'espai fluvial. Agència Catalana de l'Aigua. Departament de Medi Ambient i Habitatge.

ACA (Agència Catalana de l'Aigua) 2011. Memòria 2011. Generalitat de Catalunya, Departament de Territori i Sostenibilitat, Barcelona, 103 pp.

Alonso-Sarría, F., López-Bermúdez, F., Conesa-García, C. 2002. Synoptic conditions producing stream rainfall events within the Mediterranean Coast of Iberian Peninsula. In Dryland Rivers. L. Bull, M. Kirkby (eds.), John Wiley \& Sons, Chichester, pp. 351-372.

Arneson, L.A., Abt, S.R. 1999. Vertical Contraction Scour at Bridges with Water Flowing Under Pressure Conditions. In Stream Stability and Scour at Highway Bridges, E.V. Richardson, P.F. Lagasse (eds.), ASCE Compendium, Reston, VA.

Brice, J.C. 1984. Assessment of Channel Stability at Bridge Sites. Transportation Research Record, Vol. 2, No. 950, Transportation Research Board, Washington, D.C. 20418.

Chin, A., Gregory, K.J. 2001. Urbanization and adjustment of ephemeral stream channels. Annals of the Association of American Geographers 91(4), 595-608.

Conesa-García, C. 2005. Les 'ramblas' du Sud-est Espagnol: systèmes hydromorphologiques en milieu méditerranéen sec. Zeitschrift für Geomorphologie 49(2), 205-224. 
Conesa-García, C., García-Lorenzo, R. 2009. The effectiveness of check dams on the control of general transitory bed scouring in semiarid catchment areas (South East Spain). Water and Environment Journal 23(1), 1-14.

Conesa-García, C., García-Lorenzo, R. 2010. Bed scour-sedimentation balance induced by check dams in semiarid catchments with different lithology. In Check Dams, Morphological Adjustments and Erosion Control in Torrential Streams, Chapter 13, C. Conesa-García, M.A. Lenzi (eds.), Nova Science Publishers, New York, pp. 283-306.

Conesa García, C., García Lorenzo, R. 2011. Factores e índices de peligrosidad de las aguas de avenida en cruces de carreteras con ramblas. Estudio aplicado a la vertiente litoral sur de la región de Murcia. Boletín de la Asociación de Geógrafos Españoles 57, 195-218.

Conesa-García, C., Caselles-Miralles, V., Sánchez-Tomás, J.M., García-Lorenzo, R. 2010. Hydraulic geometry, GIS and remote sensing techniques against rainfall-runoff models for estimating flood magnitude in ephemeral fluvial systems. Remote Sensing 2(11), 2607-2628.

Deng, L., Cai, C.S. 2010. Bridge Scour: Prediction, Modeling, Monitoring, and Countermeasures-Review. Practice Periodical on Structural Design and Construction (ASCE) 15(2), $10 \mathrm{pp}$.

Federal Highway Administration 2001. Evaluating Scour at Bridges. Hydraulic Engineering Circular 18, Federal Highway Administration, U.S. Department of Transportation, Washington, DC.

Furniss, M.J., Ledwith, T.S., Love, M.A., McFadin, B.C., Flanagan, S.A. 2002. Response of Road-stream Crossings to Large Flood Events in Washington, Oregon, and Northern California. United States Department of Agriculture, Forest Service, Technology and Development Center, San Dimas.

García Lorenzo, R., Conesa García, C. 2011. Estimación de caudales de avenida y delimitación de áreas inundables mediante métodos hidrometeorológicos e hidráulicos y técnicas SIG. Estudio aplicado al litoral sur de la región de Murcia. Papeles de Geografía 53-54, 107-123.

Jaén Diego, P., Romana García, M. 2004. Diseño de obras de drenaje transversal. Carreteras: Revista técnica de la Asociación Española de la Carretera 136, 32-50.

Hjulstrom, F. 1935. The Morphological Activity of Rivers as Illustrated by River Fyris. Bull. Geol. Inst. Uppsala 25, 89-122.

Konrad, C.P., Booth, D.B. 2002. Hydrologic trends associated with urban development for selected streams in western Washington. U.S. Geological Survey Water-Resources Investigations Report 02-4040, 40 pp.

Kranc, S.C., Romano, F., Droz, E., Deavers, R., Wilmot, J., Ethier, S., Rabens, G. 1997. Hydraulic performance of structures for bridge drainage. National Technical Information Service, USA, $37 \mathrm{pp}$.

Lagasse, P.F., Richardson, E.V., Schall, J.D. 1998. Instrumentation for Monitoring Scour at Bridges. Transportation Research Record No. 1647, Highway Facility Design, Transportation Research Board, National Research Council, National Academies of Science, Washington, DC.

Lagasse, P.F., Schall, J.D., Richarson, E.V. 2001a. Stream Stability at Highway Structures. Hydraulic Engineering Circular 20, Third Edition, FHWA NHI 01-002. Federal Highway Administration, U.S. Department of Transportation, Washington, DC.

Lagasse, P.F., Zevenbergen, L.W., Schall, J.D., Clopper, P.E. 2001b. Bridge Scour and Stream Instability Countermeasures. Hydraulic Engineering Circular 23, Second Edition, FHWA NHI -01-003, Federal Highway Administration, Washington, DC.

Lischtvan, L.L., Lebediev, V.V. 1959. Gidrologia i Gidraulika v Mostovom Doroshnom, Straitielvie. Leningrad (Hydrology and Hydraulics in Bridge and Road Building), Gidrometeoizdat, Leningrad. 
Levi, J. 1981. Bed-Load Transport -Theory and Practice. Water Resources Publ., Michigan, pp. 303-355.

Lounis, Z. 2004. Risk-based maintenance optimization of bridge structures. 2nd International Colloquium on Advanced Structural Reliability Analysis Network (ASRANet), Barcelona, Spain, pp. 1-9.

Maizels, J.K. 1983. Palaeovelocity and palaeodischarge determination for coarse gravel deposits. In Background to Palaeohydrology: A Perspective, K.J. Gregory (ed.), John Wiley \& Sons, New York, pp. 101-139.

Martín Vide, J.P. 1997. Ingeniería Fluvial. Politext 58, Àrea d'Enginyería Civil. Ediciones UPC, Universitat Politècnica de Catalunya, Barcelona, 209 pp.

Martín Vide, J.P., Roselló Estelrich, R., Niñerola Chifoni, D., Gómez Navarro, L. 1993. La avenida del 9 de septiembre de 1992 en la riera de las Arenas. Departamento de Ingeniería Hidráulica, Marítima y Ambiental, Universidad Politécnica de Cataluña, Barcelona.

Maza, J.A., García Flores, M. 1997. Velocidades medias para el inicio del movimiento de partículas. V Congreso Nacional de Hidráulica, Guadalajara, pp. 70-88.

MOPU 1965. Instrucción de Carreteras 5.1-IC "Drenaje” MOPU - Ministerio de Obras Públicas y Urbanismo, Orden Ministerial de 21 de junio 1965. Madrid, BOE, 17 de septiembre de 1965.

MOPU 1990. Norma 5,1-I.C., Instrucción de carreteras. Dirección General de Carreteras, MOPU.

NCHRP 1979. Bridge Drainage Systems. National Cooperative Highway Research Program (USA), Synthesis of Highway Practices 67.

Neill, C.R. 1968. Note on initial movement of coarse uniform bed material. Journal of Hydraulic Research 6(2), 157-184.

Neill, C.R. (ed) 1973. Guide to Bridge Hydraulics. Roads and Transportation Association of Canada, University of Toronto Press, Toronto, Canada.

NRB 1977. Highway Surface Drainage - Design Guide for Highways with a Positive Collection System. National Roads Board, USA.

Pedernal Álvarez, J., Barahona Fernández, I. 2004. Localización. Carreteras. Revista técnica de la Asociación Española de la Carretera 136, 120-138.

Richardson, E.V., Davis, S.R. 2001. Evaluating Scour at Bridges. Hydraulic Engineering Circular 18, Fourth Edition, FHWA NHI 01-001, Federal Highway Administration, US Department of Transportation, Washington, DC.

Richardson, E.V., Simons, D.B., Lagasse, P.F. 2001. River Engineering for Highway Encroachments - Highways in the River Environment. Hydraulic Design Series 6, FHWA NHI 01-004, Federal Highway Administration, Washington, DC.

Shields, A. 1936. Anwendung der Änlichkeits-Mechanik und der Turbulenzforschung auf die Geschiebe-bewegung. Preussische Versuchsanstalt für Wasserbau und Schiffbau 26, Berlin.

Sobanjo, J., Mtenga, P., Rambo-Roddenberry, M. 2010. Reliability-Based Modeling of Bridge Deterioration Hazards. Journal of Bridge Engineering 15 (6), 671-684.

TRB (1999). 1998 Scanning Review of European Practice for Bridge Scour and Stream Instability Countermeasures. Transportation Research Board. National Cooperative Highway Research Program, Research Results Digest, No 241, Washington, DC.

US Department of Transportation 2001. Bridge Scour and Stream Instability Countermeasures. Experience, Selection, and Design Guidance, Third Edition, Publication No. FHWA NHI HEC-23, Federal Highway Aministration, Washington, DC.

US Department of Transportation 2009. Evaluating Scour at Bridges, Fourth Edition, Publication No. FHWA NHI 01-001, Federal Highway Administration, Washington, DC. 
Van Rijn, L.C. 1984. Sediment Transport: Bed-Load Transport, Part I. J. Hydraulic Eng. ASCE 10(11), 1431-1456.

Venditti, J.G., Dietrich, W.E., Nelson, P.A., Wydzga, M.A., Fadde, J., Sklar, L. 2010. Mobilization of coarse surface layers in gravel-bedded rivers by finer gravel bedload. Water Resources Research 46, W07506.

Woo, D.C. 1988. Bridge Drainage System Needs Criteria. Public Roads 52 (2).

Yang, T., Hsu, Y.S. 2010. Risk-based Multiobjective Optimization Model for Bridge Maintenance Planning. In Proceedings of the 2nd International Symposium on Computational Mechanics and the 12th International Conference on the Enhancement and Promotion of Computational Methods in Engineering and Science, AIP American Institute of Physics, 1233, pp. 477-482. 